Departamento de Anatomia Descritiva dos Animais Domésticos Diretor - Prof. Dr. M. Barros Erhart

Departamento de Indústria, Inspeção e Conservação de Produtos

Alimentícios de Origem Animal

Prof. contratado - Paschoal Mucciolo

\title{
CÓRTES DE CARNE BOVINA EM SÃO PAULO - BASES ÓSSEA E MUSCULAR DOS DIVERSOS SEGMENTOS (*)
}

POR

\section{Paschoal Mucciolo}

E

Orlando Marques de Paiva, Assistente

Com 12 figuras

Reveste-se certamente de muita importância o conhecimento exato, por parte do inspetor de carnes, do modo pelo qual se retalham no mercado varejista as carcassas para que possam ser dadas a consumo.

A fiscalização sanitária nesse setor do comércio de carnes não está afeta, entre nós, a profissionais da veterinária a semelhança do que acontece em alguns centros europeus em que o contrôle de preços nas feiras e mercados é função do técnico incumbido de vigiar tambem pela sanidade das carnes. Apezar disso, lembramos que dos Matadouros e Frigoríficos muitas vezes as carcassas são retalhadas e, sob essa forma, são expedidas, implicando tal fato no conhecimento seguro das peças constantes do certificado de sanidade para assegurar contrôle perfeito das mesmas.

O assunto abordado neste trabalho é fruto de observações realizadas em Matadouros e açougues desta Capital, onde colhemos todos os dados que aquí consignamos para dar a conhecer a veterinários e estudantes, de modo acessivel, o tipo de córtes de carne bovina adotado no mercado de São Paulo. Deixaremos para ulterior publicação o estudo dos córtes dos outros animais de açougue, trabalho êsse já em elaboração.

Não é nosso propósito incluir neste estudo a apreciação da qualidade no animal vivo, limitando-nos a dizer entretanto que, para o tipo cidade, são classificados os bovinos cujo rendimento (pêso frio) oscile entre 200 e 220 quilos.

Antes de iniciarmos a exposição concernente ao retalho das carcassas nos açougues, parece-nos oportuno referir, de passagem, o 
modo de apreciar a qualidade das carnes, isto é, o conjunto de caracteres exigidos pelo consumidor, determinantes do produto ser enquadrado nas diversas categorias.

Em terminologia de açougue dá-se o nome de carne à carcassa completa incluindo tecido muscular, conjuntivo, gordura e ossos e sua qualidade é apreciada no que diz respeito aos caracteres dos músculos, da gordura, da idade do animal, etc..

Quanto aos caracteres físicos da musculatura, além do volume e consistência, a qualidade da carne se prende ainda à textura, suco e coloração.

Do volume depende a maior ou menor quantidade em substância nutritiva e deve ser em proporção tal a corresponder ao tipo do chamado animal de açougue, enquanto a consistência não deve ser extrema nem em dureza nem em flacidez o que importaria em prejuizo no valor nutritivo da carne.

A textura, evidenciada pela superficie de córte, é dada pelo diâmetro dos feixes musculares, isto é, o grão da carne sendo fino deve dar ao tacto sensação doce semelhante ao veludo. Nestas condições o tecido conjuntivo intersticial será mais facilmente impregnado de gordura, resultando daí a maciez da carne, peculiar às raças especializadas para córte, como veremos mais adiante.

O suco, serosidade que aparece ao ser seccionada a carne, representando o mioplasma da fibrila muscular, deve ser abundante e de coloração rósea indicando riqueza em mio-hemoglobina e daí não só o estado de saude e idade do animal como tambem o valor nutritivo da carne em questão. Nos animais de 2 a 3 anos, de raças selecionadas com orientação para córte, o suco da carne é abundante, róseo intenso, contribuindo, em parte, para diminuir a consistência da carne e torná-la mais facilmente apreciavel ao paladar do consumidor.

A côr da carne, bastante variavel com a idade, sexo, raça, alimentação e estado de saude do animal, é vermelho-viva na carne fresca de rês recentemente abatida podendo apresentar tonalidades diversas não só de acôrdo com a perfeição da sangria, como tambem com a temperatura e estado higroscópico do ambiente.

Dada pela hemoglobina, a côr da carne torna-se mais intensa e quando exposta ao ar por muito tempo se enegrece, sendo assim encontrada frequentemente nos açougues.

De acôrdo com CRISTOL a hemoglobina, pigmento animal, é um cromoprotido possuindo em sua molécula quatro aneis pirrólicos ligados ao ferro, enquanto, para a clorofila, pigmento vegetal, os aneis pirrólicos estão ligados ao magnésio. A hemoglobina, pigmento que 
nos interessa, apresenta duas variedades: sanguínea e muscular, fisiologicamente diferentes embora de constituição química semelhante, isto é, em ambas a análise revelou serem formadas por um grupamento prostético, responsavel pela côr, ligado a uma globina.

O grupo prostético pode ser representado pela hematina ou hemocromogênio, êste último mais pobre em oxigênio. Quando duas moléculas de oxigênio se combinam a uma de ferro, (valência dupla), teremos a oxi-hemoglobina que é instavel. Si a oxidação for mais intensa resultará a meta-hemoglobina, com tres moléculas de oxigênio (valência tripla do ferro) em combinação estavel.

A esta oxidação mais intensa do pigmento, parece-nos, deve ser atribuida a coloração negra das carnes, encarada por muitos autores como resultante da passagem da mi-oxi-hemoglobina para a mio-metahemoglobina e não como afirmam PIETTRE e VILA «simples hemoglobina modificada por uma deshidratação mais ou menos profunda». De fato, nos dias quentes em que a evaporação se processa mais rapidamente, o enegrecimento aparece mais cedo e é mais evidente, justificando em parte a afirmativa dêstes autores. Acreditamos entretanto, insuficiente êste argumento para por si só explicar o fenômeno.

A gordura se distribue na carcassa quer formando acúmulos nas grandes cavidades, quer espalhando-se pela superfície, depositando-se no extrato profundo da tela subcutânea ou então impregnando o tecido conjuntivo das fibras musculares. A gordura encontrada na bacia, sob a pleura costal e na loja renal é retirada pelo açougueiro e vendida, como sebo, para fins industriais. $\mathrm{O}$ mesmo acontece frequentemente com a gordura de cobertura que, apezar de influir sobremodo nos caracteres organolépticos da carne, tornando-a mais facilmente digestivel e portanto de maior valor nutritivo, é tambem retirada para atender às exigências de alguns mercados. Sem dúvida, a excessiva gordura de cobertura, especialmente para as nossas condições de clima tropical, empresta à carne característico gôsto de ranço, enjoativo e desagradavel, sobretudo quando a mesma esteve exposta ao ar e à luz por muito tempo.

O mesmo não acontece com a gordura intersticial da musculatura, chamada de jaspeadura e que impregna o tecido conjuntivo endo-muscular, separando de certo modo os feixes de fibras, dando ao músculo, na superfície de córte, o aspecto marmóreo característico dos animais bem nutridos de raças especializadas, o que não se verifica para os animais cuja aptidão zootécnica não foi orientada para o córte. 
A boa jaspeadura contribue eficientemente para modificar todos os caracteres físicos da carne, tornando-a de coloração inconfundivel pela alternância do músculo e gordura, mais saborosa e apetecivel. Essa gordura de infiltração deve se apresentar branca rosada e de consistência própria emprestando ao conjunto aspecto agradavel.

Quando se prepara um pedaço de carne de boa jaspeadura, a gordura se funde, formando-se uma película em volta da fibra muscular, aprisionando por assim dizer as substâncias extrativas nitrogenadas de que deriva o cheiro peculiar da carne, contribuindo tambem para o amolecimento da própria fibra. Resulta daí a carne cozida ser suculenta, macia e saborosa. Por outro lado, um pedaço de carne sem jaspeadura, o que se verifica nos animais velhos e exgotados, cuja finalidade foi outra que a de açougue, o calor provoca a evaporação da água de constituição da carne, as substâncias extrativas azotadas passam da carne para o môlho, obtendo-se um produto cozido duro, sêco e sem gôsto.

O conjunto de caracteres que acabámos de expor, cuja delicadeza de apreciação depende muito da agudeza do observador e sobretudo do contacto diário com as cousas de açougue, determina a qualidade ou categoria da carne.

Abatido e sangrado, o animal é sujeito a tôdas as manipulações de esfolamento, eventração, evisceração, limpeza, retirada da cabeça e cauda separadas, respectivamente, ao nivel das articulações occípitoatloidéia e sacro-coccigéia, operações necessárias para entrarem as carcassas em contacto com o mercado consumidor. Ainda nos Matadouros, as carcassas inteiras de bovinos, objetivo único dêste trabalho, são serradas ao meio, ao longo do plano sagital mediano, córte êsse interessando a coluna vertebral em tôda a sua extensão, apanhando tambem o esterno, daí resultando os antímeros conhecidos por meias carcassas. Os membros se apresentam por sua vez livres dos segmentos mais distais compreendendo metacarpo, metatarso e falanges desarticulados ao nivel das articulações carpo-metacárpica e tarso-metatársica.

Destinando-se ao abastecimento da cidade de São Paulo, as carcassas além de serem despojadas dos rins e respectivas lojas gordurosas, sofrem ainda outra divisão por um córte praticado no $5 .^{\circ}$ espaço intercostal, córte êsse completado, com auxílio da serra, ao nivel da coluna e do esterno (Fig. I, a a'). 
Temos assim a carcassa dividida em quatro porções das quais as duas craniais são conhecidas como quartos dianteiros e as caudais como quartos trazeiros.

O quarto dianteiro compreende, portanto, as seguintes porções:

a) porção cranial do gradil torácico que inclue as cinco primeiras costelas;

b) membro torácico tendo o segmento mais distal desarticulado na articulação carpo-metacárpica;

c) pescoço ;

O quarto trazeiro compreende:

a) porção caudal do tronco, a partir da 6. ${ }^{a}$ costela, inclusive;

b) membro pélvico tendo desarticulado seu segmento mais distal ao nivel da articulação tarso-metatársica.

Os quatro quartos obtidos pela divisão da carcassa constituem assim a "carne limpa» e, nestas condições, saem do matadouro para o tendal do açougueiro, depois de passar pelo entreposto, desobrigando-se do fisco e da reinspeção sanitária.

Apresentam-se os quartos ao açougueiro, não como produto já pronto para a venda, posto que, constituido de um conjunto heterogêneo de peças de valor diferente, devem ser por êle separadas, obedecendo a uma técnica peculiar determinada por uma Anatomia inconsciente, na expressão de J. PoIsson, satisfazendo contudo os hábitos do consumidor.

Reconhecer os diferentes segmentos pela côr e forma e separálos racionalmente sempre do mesmo modo, no que o retalhista é guiado por verdadeiro automatismo, é a operação chamada na gíria de açougue, de «desmanchar».

P. Roux, professor da Escola de Agricultura de Rennes e diretor dos Matadouros dessa mesma cidade, em interessante trabalho acêrca da regulamentação do mercado varejista de carne em França, propõe o têrmo Creologia (De Krèas) para designar o estudo da técnica de córtes e reconhecimento dos diversos segmentos dos quartos nos açougues, creando mesmo, sôbre o assunto em questão, um curso na Escola Nacional de Coëtlogon - Rennes.

E' sabido que o modo de praticar os córtes e as categorias em que são catalogados os segmentos resultantes, varia de uma cidade a outra e às vezes na mesma cidade, sendo essa diversidade na técnica de córte acompanhada de perto pela mais variada nomenclatura. 
Seria materialmente impossivel uniformizar os córtes e sua nomenclatura para as diversas regiões de um mesmo país, sem intervenção oficial, devido aos costumes próprios, inerentes a elas e às necessidades e hábitos do consumidor. E' assim que, pelo decreto n. ${ }^{\circ} 1458$, de 26 de setembro de 1930 do govêrno italiano, foi adotado o córte único em tôdas as cidades do reino, sem cogitar entretanto da unificação da nomenclatura dos diversos segmentos.

A terminologia não só varia de região para região como tambem frequentemente com a vontade do retalhista interessado em estabelecer confusões. A êste respeito nada poderia ser mais expressivo do que o trecho de Roux, referindo-se a equívocos estabelecidos quando um mesmo vocábulo designa segmentos diferentes e que transcrevemos na íntegra: "Un Parisien qui demandera de la Hampe (diaphragme) recevra du Flanchet (tunique abdominale) d'un boucher de Marseille. S'il demande du Faux-Filet, il recevra de l'onglet (piliers du diaphragme) à Nancy, à Lille ou à Troyes, du romstec à Toulouse! »

Por outro lado, os exemplos do mesmo segmento ser indicado por nomes diversos são bastante frequentes e mesmo entre nós se observam. E' o caso do coxão mole como é conhecido em São Paulo, seccionado do mesmo modo e abrangendo a mesma base muscular, ser chamado de chã de dentro na Capital Federal e em Pernambuco.

Não é raro, contudo, o fato de populações se abastecerem de carne bovina, sem a preocupação da divisão metódica da carcassa, pagando preço único qualquer que seja o segmento considerado. Neste caso estão algumas cidades de Portugal, de que nos dá conta o trabalho de J. Miranda do Valle, onde a carne é vendida sem distinção de categorias, apenas reportadas a carne com ou sem osso.

Idêntico fato se verifica na Síria com respeito aos bovinos, como refere MARCEL SABa. Não ha em todo o país classificação por ordem de valor venal nas diferentes partes da carcassa. O cliente escolhe o pedaço desejado sôbre a carcassa e o açougueiro executa o córte do segmento sem alteração no preço da compra.

Dissemos linhas acima que o córte das carnes varia com as regiões encaradas e tambem com o próprio retalhista, podendo isto parecer que a técnica de córtes e as categorias nas quais se enquadram sejam arbitrárias, não havendo nada de definitivo senão a fantasia creada pelo açougueiro e pelo consumidor. Entretanto, um hábito de origem muito remota, calcado na experiência transmitida através de gerações conseguiu grupar os diferentes músculos em segmentos determinados por uma anatomia tôda especial (H. MARTEL). 
A primeira justificativa dos córtes procedidos, visando submeter sua técnica à crítica científica com escopo de racionalizá-la talvez, foi dada por KüHN (cit. BERTOLINı). Êste autor atribuia a diferença de preços dos diversos segmentos à composição química dos mesmos, conferindo um mesmo valor comercial aos tecidos gorduroso e muscular.

G. Martinoli (cit. Bertolini), examinando a média de análises químicas da carne de animais de várias espécies em diferentes estados de engorda, pôude contestar a afirmativa de KüHN, mostrando que as diferenças de composição da carne encontradas por êste último autor são devidas tão somente à quantidade de gordura. A conclusão de Martinoli, no que é seguido por Kramer (cit. Bertolini), é negar à composição química das carnes a razão de, por si só, explicar suficientemente a diferença de preços alcançados no açougue pelos diversos segmentos da carcassa.

Parece mais lógico pois, atribuir a classificação dos segmentos ao conjunto de caracteres físicos e organolépticos, fazendo ressaltar a relação músculo-osso, variavel de acôrdo com o segmento considerado. A quantidade de aponevroses e tendões, contribuindo seriamente para determinar maior consistência da carne teria, a nosso ver, papel ponderavel na classificação das diversas porções, fazendo oscilar seus preços desde que constituem porções de valor nulo sob o ponto de vista alimentar. Devemos lembrar tambem que a classificação em categorias, nas quais se enquadram os segmentos, está baseada de algum modo no paladar do consumidor, sendo nesse caso subjetiva. Exemplo frizante desta nossa asserção reside no fato de que, um segmento tido como de primeira categoria em certa localidade e pago como tal, pode não o ser em outra, onde, por um mixto dos ditames da culinária e do capricho do paladar dos habitantes fica relegado a um segundo plano.

Achamos interessante referir a esse proposito o modo de catalogar os segmentos em Montevidéu, com relação ao mercado de São Paulo. Segundo TORRES DE LA LlosSA, da primeira categoria faz parte a região do lombo unicamente, da segunda o costado $(2 / 3$ ventrais das paredes torácica e abdominal), da terceira todo o coxão, enquanto as regiões do pescoço, membro torácico e peito se agrupam na quarta categoria.

E' preciso tambem reconhecer que os segmentos agrupados nas melhores categorias e daí alcançando preço mais elevado são aqueles que se prestam melhor a diferentes fins da culinária, podendo ser manipulados de diversos modos. 


\section{TÉCNICA DE CÓRTE TIPO SÃO PAULO}

A técnica usada na segmentação e como são conhecidas as várias porções enquadradas nas diversas categorias, de acôrdo com seu valor venal, é o que passaremos a estudar, visando as características do mercado varejista de São Paulo, dando em apêndice, algumas notas referentes ao mercado da Capital Federal. Para isso tivemos ocasião de acompanhar em vários açougues dêsses dois grandes centros consumidores o trabalho efetuado pelos retalhistas, parecendo-nos esta a melhor fonte de dados seguros.

Observámos assim que, de modo geral, os córtes são praticados com a mesma orientação para a mesma localidade; tambem a sequência é, salvo ligeiras variantes de mínima importância, igual em todos os açougues, facilitando uma descrição comum da técnica para todos êles.

\section{DIVISÃO DO DIANTEIRO}

Suspenso o dianteiro por um gancho implantado junto ao esterno, na altura do $4 .^{\circ}$ espaço intercostal, inicia-se a divisão do mesmo por um córte longitudinal feito à serra, pelo lado interno do torax, extendendo-se da 5.a costela até à 1.a (Fig. I, b b'). A altura e orientação dêste córte são dadas por uma linha que, seccionando ao meio a quinta costela, se prolonga para diante até à primeira, paralelamente à coluna. Cranialmente à primeira costela, ainda com a mesma orientação dada pelo córte descrito, e sempre do lado interno da carcassa, é seccionado à faca o m. esternocefálico junto ao esterno (Fig. V, d). Prosseguindo, seccionam-se os $\mathrm{mm}$. braquiocefálico e omotraqueliano rente às suas inserções apendiculares; inicia-se tambem o córte da porção cervical do $\mathrm{m}$. trapézio, margeando o m. supraespinhoso (Fig. V, c c').

Neste momento a peça que inclue a região cervical e porção dorsal do gradil torácico se acha pendente do outro segmento, formado pela metade do gradil e membro torácico, prêso pelas inserções dos mm. denteado ventral do torax e angular da espádua, na face interna da escápula, pela inserção do m. rombóide sôbre a cartilagem do mesmo osso e ainda superficialmente pela inserção da porção dorsal do m. trapézio na espinha da escápula, posto que a porção cervical já foi seccionada (Fig. VII).

Continuando, rente às inserções escapulares, desinserem-se os mm. angular da espádua, denteado ventral do torax, secciona-se a cartilagem da escápula ao longo de sua implantação na margem dorsal dêste osso (Fig. VI, c c') e completa-se o córte do trapézio, ao nivel de sua porção dorsal. 
Destaca-se assim a peça que compreende a metade dorsal do gradil torácico e pescoço, ao passo que o membro anterior e a parte ventral do gradil torácico, ainda reunidos pelos músculos peitorais, constituem a outra porção.

A primeira peça, compreendendo a porção dorsal do gradil torácico e pescoço, é dividida por uma secção muscular vertical que interessando a 7.a vértebra cervical desce cranialmente ao longo da margem anterior da 1.a costela (Fig. I, c c'); a porção cranial resultante desta divisão é denominada pescoço; a caudal assem (Fig. I, 1 e 2).

Quanto à segunda peça, que compreende o membro torácico e metade ventral do gradil costal, é tambem dividida em dois segmentos após córte dos $\mathrm{mm}$. peitorais ( $\mathrm{mm}$. esternohumeral, esternopreescapular, esternoaponevrótico, esternotroquiniano) junto às suas inserções apendiculares.

Os segmentos resultantes são: -a metade ventral do torax e o membro torácico, denominados respectivamente de peito e braço (Fig. I, 3 e 4).

Dêstes segmentos apenas o braço ou membro torácico deve ainda sofrer uma série de operações que passaremos a descrever: procede-se primeiramente à retirada dos músculos situados na face dorsal do rádio e húmero isto é, dos mm. extensor anterior do metacarpo e bíceps braquial (Fig. II, 1).

O descolamento dêstes músculos se faz no sentido distal-proximal sendo o tendão do $\mathrm{m}$. bíceps seccionado ao nivel da articulação escápulo-humeral. Sôbre o rádio e o cúbito tambem de baixo para cima pratica-se a seguir, com auxílio da serra uma série de córtes transversais, equidistantes e incompletos em direção médio-lateral (Fig. II). O último dêstes córtes, feito ao nivel da articulação do cotovelo, abre a cavidade articular e vai interessar o olécrano, ou seja, a porção do cúbito que ultrapassa dorsalmente o rádio. Êstes dois segmentos retirados separadamente do membro anterior ou braço são vendidos: o primeiro como músculo e como contrapêso o segundo (Fig. II, 1 e 2).

No segmento restante, compreendendo as regiões escapular e braquial (da qual foi separado o m. bíceps), procede o retalhista à desossa parcial mediante a retirada do húmero. Para isso secciona rente às suas inserções, na face medial do húmero, os $\mathrm{mm}$. coracobraquial, mediano extensor do antebraço e o tendão comum dos mm. grande redondo e grande dorsal. Prosseguindo corta a inserção troquiniana do m. supraespinhoso e o tendão do m. subescapular; depois de abrir a articulação escápulo-humeral secciona à machado o tro- 
quíter. Para finalizar, acompanhando a face lateral do húmero, desinsere os $\mathrm{mm}$. deltóide, curto extensor do antebraço, pequeno redondo, braquial anterior e anconêo isolando desta forma o húmero. Após a retirada dêste osso é o segmento posto à venda e conhecido como braço propriamente dito (Fig. II, 3).

\section{DIVISÃO DO TRASEIRO}

Suspenso o traseiro por um gancho implantado no $6 .{ }^{\circ}$ espaço intercostal, próximo ao esterno, as operações se iniciam com a retirada da massa gordurosa acumulada na prega do gordinho e do $\mathrm{m}$. reto do abdomen (Fig. I, d d') que é seccionado, de um lado, ao nivel do gradil costal e, de outro, cranialmente ao pubis. Êste músculo é vendido sob a denominação de fraldinha (Fig. I, 5).

Em continuação, isola-se completamente $\mathrm{o} \mathrm{m}$. tensor da fascia lata da face lateral da coxa sempre seguindo pelo interstício muscular de modo a ficar o mesmo prêso pela inserção proximal (Fig. V, d f). Esta operação põe a descoberto e facilita a secção transversal dos $\mathrm{mm}$. reto anterior da coxa, grande psoas e sartório na altura da articulação coxo-femural.

Isto feito, com o auxílio da serra, pratica-se um córte em tôda a espessura do coxal, ao nivel do supercílio da cavidade cotilóide, com orientação crânio-caudal e, passando acima da pequena incisura isquiática, atinge-se pequena porção da tuberosidade do ísquio. Conforme a inclinação da serra êste córte pode interessar a cavidade cotilóide, pequena porção da cabeça femural e o grande trocanter, prolongando-se neste caso sôbre parte do ramo cotiloideo do ísquio e terminando como o primeiro por seccionar pequena porção da tuberosidade isquiática (Figs. I, e e' $-\mathrm{V}, \mathrm{f}$ d').

Como se verifica, o traseiro é, mediante êste córte, dividido em duas porções:

$1 .^{\circ}$ ) - Uma porção cranial, por alguns denominada «barca», que inclue a porção ilíaca do coxal, sacro e tôda a coluna e gradil torácico até à 6. ${ }^{a}$ costela, inclusive (Fig. I, x);

$2 .^{\circ}$ ) uma porção caudal, ou coxão, que compreende as partes pubiana e isquiática do coxal e o membro pélvico desarticulado na articulação tarso-metatársica (Figs. I, y - III, 5).

a) A «barca», ou traseiro sem o coxão, ainda suspensa pelo gancho é dividida em dois segmentos mediante um córte longitudinal feito à serra pela face interna do torax, a partir do limite entre o terço dorsal e os dois terços ventrais, mais ou menos, da 6. ${ }^{a}$ costela em direção caudal, segundo uma linha, aproximadamente, paralela à 
coluna (Fig. I, f f'). Êste córte secciona tôdas as costelas a partir da $6 .^{a}$ e a parede abdominal, dele resultando uma parte dorsal e outra ventral da «barca». A parte ventral constitue a chamada ponta de agulha (Fig. I, 6).

A parte dorsal compreende tres segmentos que são, enumerados no sentido crânio-caudal: - o filet de costela, o filet de lombo e o alcatre (Fig. I, 7, 8 e 9). O primeiro segmento é separado dos dois outros, mediante um córte vertical praticado ao nivel da última vértebra torácica e que, se extendendo por tôda a altura da peça, vai, evidentemente, atingir a décima segunda e décima primeira costelas, dada a normal inclinação das mesmas (Fig. I, g g'). À porção isolada dá-se o nome de filet de costela ou bisteca. O segmento restante compreendendo o filet de lombo e o alcatre é dividido em duas porções por uma secção tambem vertical que, interessando a 5 . $^{\mathrm{a}}$ ou

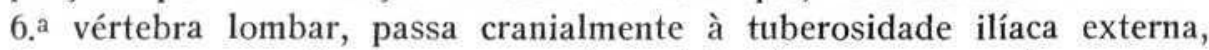
tomada como ponto de reparo pelos retalhistas e comumente por êles denominada «capitão» (Fig. I, h h'). Das duas porções resultantes a cranial constitue o filet de lombo e a caudal o alcatre.

b) A porção caudal ou coxão, como vimos, compreende as partes pubiana e isquiática do coxal e o membro pélvico.

Dando início ao retalho do coxão primeiramente são feitos dois córtes incompletos sendo um ao nivel da epífise distal da tíbia e outro 10 centímetros acima dêste, sôbre a diáfise dêsse mesmo osso (Fig. IV, a b). Estes dois segmentos são vendidos como contrapêso (Fig. IV, 3).

Em seguida procede-se ao descolamento da massa muscular alojada na face antero-externa da tíbia, representada pelo grupo dos músculos extensores do metatarso e falanges que são seccionados longitudinalmente, ficando a descoberto a face dêsse osso (Fig. IV, c). Prosseguindo, secciona-se tambem em sentido longitudinal a massa muscular aplicada à face volar da tíbia, representada pelo grupo dos músculos flexores do metatarso e falanges (Fig. X, f f' - abaixo da articulação do joelho).

Em continuação, disseca-se o quadríceps femural separando-o lateralmente do $\mathrm{m}$. longo vasto (Fig. IX, a f) e medialmente do $\mathrm{m}$. sartório (Figs. VIII, a a' - IX, c f). Seguindo o interstício muscular entre o quadríceps e os músculos citados, em tôda a extensão, atinge-se medial e lateralmente, as inserções dos $\mathrm{mm}$. vasto medial e vasto lateral, ao longo das margens interna e externa do femur, sem as seccionar. A seguir, cortam-se os ligamentos tíbio-rotulianos, mais ou menos em sua metade, de modo a deixar a rótula ligada ao femur pelos ligamentos fêmuro-rotulianos e músculo quadríceps (Fig. IV, d). 
Descoberta a tróclea, é a mesma seccionada a meia altura no sentido dorso-volar em tôda a espessura da epífise distal do femur passando o córte acima dos côndilos dêsse osso (Fig. IV, e). Êste córte é iniciado com a serra e completado à machado. Agora, já ao nivel da face posterior do femur, são seccionados rente às suas inserções e em sentido distal-proximal todos os músculos que se inserem nessa face (mm. adutor, pectíneo, quadrado femural, obturadores interno e externo e gêmeos da bacia). Desta forma pode-se destacar o femur, após córte da cápsula articular coxo-femural e ligamento redondo. E' evidente que, no caso do ápice do trocanter não ser seccionado quando se procede a separação da "barca» e "coxão» para se completar a retirada do femur, necessário se torna cortar as inserções dos glúteos. Juntamente com o femur são retiradas tambem as quatro porções do m. quadríceps, que permanece aplicado pelas suas inserções sôbre a face cranial do femur, assim como a rótula prêsa pelo músculo quadríceps e ligamentos fêmuro-rotulianos.

A esta primeira peça a ser isolada do coxão dá-se o nome de patinho (Figs. IV, 1 - IX, 1).

Retirado o patinho do coxão resta-nos a massa muscular das regiões crurais interna e posterior e o $\mathrm{m}$. sartório, ainda reunidos em uma peça única.

Prosseguindo, separam-se os músculos da região crural posterior, ao longo do interstício muscular entre os $\mathrm{mm}$. semitendinoso e semimembranoso (Figs. IX, d f - X, f f' - acima da articulação do joelho); tal córte prolongado para cima vai atingir a tuberosidade isquiática, ponto de origem dêstes músculos, que é seccionada à machado. Esta secção sendo aprofundada põe a descoberto primeiro a massa dos mm. gastrocnêmios, depois o poplitêo e os secciona ainda segundo o eixo longitudinal que orientou o córte anterior. Esta incisão termina por encontrar o córte dos mm. flexores do metatarso e das falanges praticado ao iniciar-se o retalho do coxão. Com o machado divide-se a metade distal da tróclea e côndilos femurais em duas porções, seguindo a fossa intercondiloidéia e a goteira troclear, separa-se tambem o côndilo lateral da tíbia do restante dêste osso, ainda com auxílio do machado, ficando assim os dois segmentos completamente isolados.

O segmento medial recebe o nome de coxão mole (Fig. IX, 2); o segmento lateral é separado, por um córte longitudinal praticado sôbre o m. longo vasto, próximo à sua margem caudal, em duas porções (Figs. V, e e' - IX, e b); a cranial, constituida pelo m. longo vasto é o coxão duro (Fig. IX, 3); a caudal, correspondente 
ao m. semitendinoso e parte mais caudal do $\mathrm{m}$. longo vasto é o lagarto (Fig. IX, 4).

Em resumo o quarto traseiro fornece: fraldinha, ponta de agulha, filet de costela, filet de lombo, alcatre, patinho, coxão mole, coxão duro e lagarto.

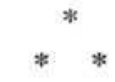

Tivemos ocasião de dizer como os retalhistas, guiados pela côr e fórma dos diversos segmentos fazem sua identificação e, por um automatismo todo próprio, tecnologia essa legada através de gerações, praticam de modo sempre idêntico os diversos córtes. Acreditamos todavia que, para veterinários e estudantes o reconhecimento deva ser baseado unicamente em caracteres anatômicos, tornando-se imprescindivel, portanto, dissecar todos os segmentos para estabelecer de modo seguro suas bases anatômicas, afim de caracterizá-los fielmente. Com êsse objetivo conseguimos do Frigorífico Armour meia carcassa de bovino sôbre a qual foram praticados os córtes por um retalhista, obedecendo à mesma técnica dos açougues; os segmentos resultantes do retalho foram injetados e conservados em formol a $10 \%$ afim de procedermos à dissecção.

\section{BASES ÓSSEa E MUSCULAR DOS DIVERSOS SEGMENTOS}

Limitar-nos-emos ao estudo das bases óssea e muscular assinalando, na medida do possivel, todo o detalhe que possa facilitar o reconhecimento das porções em estudo, adotando a terminologia, baseada sôbre o plano de construção do corpo dos vertebrados e seguida por Bruni, in U. ZimMERL.

\section{DIANTEIRO}

Pescoço: (Fig. I, 1).

Base óssea - 7 vértebras cervicais seccionadas ao meio.

Base muscular - Este segmento compreende tôda a região cervical abrangendo dois grupos musculares situados, dorsal e ventralmente, à porção correspondente da coluna vertebral (Fig. XI).

No grupo ventral distinguimos 4 planos musculares. O plano mais profundo é formado pelos músculos pré-vertebrais (mm. reto lateral da cabeça, reto ventral da cabeça, longo da cabeça e longo do pescoço); em um segundo plano se dispõem os músculos escalenos (mm. escaleno supracostal, escaleno da 1.a costela e escaleno mínimo) colocados lateralmente à coluna; a seguir os músculos pré-traqueiais ou sub-ioideos (mm. esternoioideo, esternotireoideo, tireoioideo, ioepiglótico e omoioideo) e finalmente o plano muscular mais super- 
ficial denominado de esternocleidomastoideo ( $\mathrm{mm}$. esternocefálico, compreendendo os $\mathrm{mm}$. esternomastoideo e esternomandibular; $\mathrm{m}$. braquiocefálico, compreendendo os $\mathrm{mm}$. cleidooccipital e cleidomastoideo e o m. omotraqueliano). Devemos assinalar desde já a ausência dos $\mathrm{mm}$. pré-traqueiais ou sub-ioideos que à exceção do m. omoioideo são retirados no matadouro com o laringe, traquéia, esôfago e língua.

Do grupo dorsal fazem parte os $\mathrm{mm}$. espinodorsais; no plano mais profundo, breves e dispostos metamericamente, encontram-se os $\mathrm{mm}$. interespinhosos e intertransversários; mais cranialmente os $\mathrm{mm}$. vertebrooccipitais ( $\mathrm{mm}$. grande e pequeno oblíquos da cabeça, o grande reto dorsal ou posterior da cabeça e pequeno reto dorsal da cabeça) formam êste plano. A êle se sobrepõe o plano representado pelos longos extensores da coluna vertebral que inclue os mm. transversoespinhoso (porção cervical), longo espinhoso (porções cervical e da cabeça ou grande complexo), longo dorsal (longuíssimo do pescoço ou transversário do pescoço; o longuíssimo do atlas e longuíssimo da cabeça ou pequeno complexo), longo costal (porção cervical ou m. cervical ascendente) e m. esplênio. Finalmente em plano mais superficial notamos parte do grupo dos mm. espinohumerais ou melhor «espinoapendiculares», como é preferivel denominá-los, compreendendo os mm. angular da espádua e as porções cervicais dos mm. rombóide e trapézio.

Assem: (Fig. I, 2).

Base óssea - 5 primeiras vértebras torácicas seccionadas ao meio; metade dorsal das 5 primeiras costelas.

Base muscular (Fig. XII) - Pela face interna observa-se sob o corpo das primeiras 5 vértebras torácicas $\mathrm{o} \mathrm{m}$. longo do pescoço e entre as costelas os $\mathrm{mm}$. intercostais internos. Pela face externa dêste segmento, profundamente, nos espaços intercostais notam-se os $\mathrm{mm}$. intercostais externos e os supracostais que representam a porção mais dorsal, individualisada, dos primeiros. Transversalmente sôbre as costelas o m. escaleno supracostal e o escaleno mínimo. Dorsalmente a estes os mm. angular da espádua e denteado ventral do torax ocupando quasi tôda a face externa do assem. $\mathrm{O} \mathrm{m}$. denteado ventral do torax é facilmente identificavel, pois, sua origem se faz mediante 6 a 9 digitações da face externa das costelas segundo uma linha de convexidade ventral (Fig. VI, i).

$\mathrm{Na}$ goteira vértebro-costal, limitada lateralmente pela união dos processos transversos com os tubérculos costais e medialmente pelos processos espinhosos das vértebras dorsais, são acolhidos os músculos pertencentes ao grupo dos espinodorsais. Notamos neste nivel 3 planos 
musculares superpostos; do plano mais profundo fazem parte os mm. interespinhosos, intertransversários, rudimentares, e, a porção dorsal do $\mathrm{m}$. transversoespinhoso. Em plano médio e no sentido dorso ventral encontram-se os mm. longo espinhoso (porção dorsal), longo dorsal (longuíssimo do dorso) e longo costal (porção dorsal). Recobrindo estes músculos o plano mais superficial constituido pelos segmentos mais caudais da porção cervical dos mm. trapézio e rombóide. A êste último está ligado um segmento da cartilagem de prolongamento do omoplata, sôbre a qual o m. rombóide se insere. Parte do $\mathrm{m}$. denteado dorsal cranial é tambem encontrada.

Peito: (Fig. I, 3).

Base óssea - Metade ventral dos 5 primeiros arcos costais e metade do esterno até à 5 . $^{\mathrm{a}}$ estérnebra.

Base muscular - (Fig. XII) - Observado êste segmento pela face interna pode-se reconhecer facilmente $\mathrm{o} \mathrm{m}$. transverso do torax quer pela sua forma quer pelas suas características digitações de inserção e os mm. intercostais internos. A face externa do peito mostra nos espaços intercostais os $\mathrm{mm}$. intercostais externos. A base muscular dêste segmento é representada em quasi sua totalidade pelos $\mathrm{mm}$. peitorais. Distinguimos assim os $\mathrm{mm}$. esternotroquiniano e esternopreescapular (rudimentar) constituindo o peitoral profundo e os mm. esternohumeral e esternoaponevrótico formando o peitoral superficial.

Profundamente aos músculos peitorais encontra-se, aplicado diretamente ao gradil costal $\mathrm{o} \mathrm{m}$. transverso das costelas; esta lâmina muscular origina-se da $1 .^{\text {a }}$ costela e se dirige caudo ventralmente para tomar inserção sôbre as cartilagens costais. $\mathrm{O}$ m. transverso das costelas continúa em direção cranial $\mathrm{o} \mathrm{m}$. reto do abdomen que concorre com uma porção pouco consideravel para formar a base muscular do peito. Sôbre o manúbrio do esterno, notam-se as inserções do $\mathrm{m}$. esternocefálico, substituido nos ruminantes pelos mm. esternomastoideo e esternomandibular.

Braço: (Fig. II, 3).

Base óssea - Omoplata sem a cartilagem de prolongamento, troquíter humeral e olécrano.

Base muscular - Neste segmento enumeraremos 2 grupos musculares correspondentes às regiões escapular e braquial (Fig. XII).

Região da espádua: compreende as regiões escapular lateral e medial ou subescapular. A primeira é formada pelos mm. supraespinhoso, infraespinhoso, deltóide e pequeno redondo; a segunda pelos mm. subescapular e grande redondo. 
Região do braço: podemos descrever dois agrupamentos musculares, um anterior, constituindo a região braquial anterior onde distinguimos os mm. coracobraquial e braquial anterior; um posterior, o grupo dos extensores do antebraço que inclue os $\mathrm{mm}$. grande extensor do antebraço, curto extensor do antebraço, mediano extensor do antebraço, anconêo e tensor da fascia antebraquial.

Músćulo: (Fig. II, 1).

Base muscular - Compreende os mm. bíceps braquial e extensor anterior do metacarpo, que são totalmente isolados das inserções ósseas.

Contrapêso: (Fig. II, 2).

Base óssea - Rádio e cúbito sem olécrano. Carpo.

Base muscular - Representada pelos mm. volares e dorsais do antebraço exceto o m. extensor do metacarpo. Dêsse modo, a região antebraquial anterior é formada pelos mm. extensor oblíquo ou lateral do metacarpo e extensor anterior das falanges dividido em dois músculos distintos: extensor comum dos dedos e extensor próprio do dedo medial; completa êste grupo o extensor lateral das falanges que nos ruminantes age como extensor próprio do dedo lateral. A região antebraquial posterior compreende os mm. flexor oblíquo do metacarpo, flexor lateral do metacarpo, flexor medial do metacarpo e os mm. flexor superficial das falanges e flexor profundo das falanges ou perfurado e perfurante. No antebraço existe ainda o m. redondo pronador que apezar de rudimentar é constante.

Aos músculos da espádua, braço e antebraço que acabámos de enumerar é necessário acrescentar as inserções dos mm. denteado ventral do torax, braquiocefálico, trapézio e peitorais representados no membro torácico por pequenos segmentos resultantes da secção que separou o membro torácico dos outros segmentos. Um pedaço de tamanho apreciavel do $\mathrm{m}$. grande dorsal vem apenso ao braço, pois êste músculo tem inserção comum com o m. grande redondo no tubérculo da face medial do húmero.

\section{TRASEIRO}

Fraldinha: (Fig. I, 5).

Base muscular - Este segmento, o primeiro a ser retirado depois de iniciado o córte do trazeiro, é inteiramente formado pelo músculo reto do abdomen. Esste músculo poligástrico é interrompido 
por uma série de intersecções tendinosas, em número de 5 nos bovinos. $\mathrm{O}$ reconhecimento da fraldinha é possivel, pela verificação em sua face profunda das intersecções características do $\mathrm{m}$. reto do abdomen.

Ponta de agulha: (Figs. I, 6 - III, 1).

Base óssea - Duas últimas estérnebras e apêndice xifóide seccionados ao meio; dois terços ventrais dos últimos oito arcos costais.

Base muscular - Na face interna da ponta de agulha notam-se os mm. intercostais internos, a porção mais caudal do $\mathrm{m}$. transverso do torax e os mm. diafragma, transverso e oblíquo interno do abdomen. A porção do m. diafragma que é visivel, corresponde às partes costal e esternal do mesmo e é representada por uma estreita lâmina carnosa que toma inserção mediante uma série de digitações um pouco acima das articulações condro-costais e na face interna do processo ensiforme ou xifóide, onde já se torna mais espêssa. As digitações do m. diafragma se engrenam com idênticas digitações do $\mathrm{m}$. transverso do abdomen, facilitando o reconhecimento da peça. Observa-se uma porção bem reduzida do centro frênico. Quanto ao $\mathrm{m}$. oblíquo interno toma inserção na face interna das cartilagens costais por uma série de digitações unindo-se aos músculos intercostais internos.

Sôbre a face externa, profundamente, vêm-se os músculos intercostais externos e as digitações de origem do $\mathrm{m}$. reto do abdomen. Dois planos musculares se sobrepõem às costelas e mm. intercostais externos, nesta face. No plano profundo, dorsalmente, encontram-se os $\mathrm{mm}$. denteado ventral do torax oblíquo externo do abdomen; ventralmente o m. peitoral profundo ( $\mathrm{m}$. esternotroquiniano ou parte ascendente do $\mathrm{m}$. peitoral profundo). Já lembrámos as características do $\mathrm{m}$. denteado ventral do torax ao tratar do assem; acrescentaremos apenas que as primeiras denteaduras do $\mathrm{m}$. oblíquo externo do abdomen se engrenam com as últimas do $\mathrm{m}$. denteado ventral do torax. No plano superficial, recobrindo os músculos precedentes, nota-se dorsalmente pequena porção do $\mathrm{m}$. grande dorsal; ventralmente a secção irregular do m. cuticular ou subcutâneo do tronco.

Filet de costela: (Figs. I, $7-\mathrm{III}, 2$ ).

Base óssea - Oito últimas vértebras dorsais divididas ao meio; terço dorsal dos 8 arcos costais correspondentes.

Base muscular - Na face interna observa-se a origem dos $\mathrm{mm}$. psoas ao nivel do corpo e margem caudal das duas últimas vértebras torácicas e costelas e ainda a inserção do m. quadrado lombar. 
Sôbre a face externa, profundamente, nos espaços intercostais, os mm. intercostais externos e supracostais; ao nivel da coluna encontramos o grupo dos espinodorsais compreendendo os $\mathrm{mm}$. interespinhosos e intertransversários dorsais. Sobrepostos a estes os mm. transversoespinhoso, longo espinhoso (porção dorsal), longo dorsal (longuíssimo do dorso) e longo costal (porção dorsal), todos êles estão representados no assem onde já foram assinalados como longos extensores da coluna, alojando-se na goteira vértebro-costal. Aplicados ao plano costal encontramos os mm. denteado dorsal cranial, denteado dorsal caudal e denteado ventral do torax. Em plano mais superficial, recobrindo os $\mathrm{mm}$. denteados, aparecem os $\mathrm{mm}$. trapézio (porção dorsal) e grande dorsal completando a base muscular do filet de costela ou bisteca. As porções dorsais do m. trapézio e do m. grande dorsal são por vezes retiradas do filet de costela, constituindo um segmento vendido à parte sob a denominação de capa do filet.

Filet de lombo: (Figs. I, 8 - III, 3).

Base óssea - Seis vértebras lombares seccionadas ao meio; segmentos dos arcos costais pertencentes à 11. ${ }^{\mathrm{a}}$, 12. ${ }^{\mathrm{a}}$ e $13 .^{\mathrm{a}}$ costelas .

Base muscular - Examinando a face interna do segmento em estudo, encontramos os $\mathrm{mm}$. intercostais internos, unindo as secções dos arcos costais a que nos referimos. Entre os processos costiformes das vértebras lombares aparecem os $\mathrm{mm}$. intertransversários da região lombar. Notam-se tambem o m. retrator da última costela que se pode considerar como uma parte destacada do $\mathrm{m}$. oblíquo interno do abdomen e o m. quadrado lombar sob os processos costiformes das vértebras lombares. $\mathrm{O} \mathrm{m}$. diafragma é representado no filet de lombo por uma porção da parte costal. A parte lombar constituida pelos pilares do diafragma é muitas vezes retirada nos matadouros e vendida com o nome de lombinho. Ainda na face interna podemos verificar os seguintes $\mathrm{mm}$. abdominais: $\mathrm{mm}$. transverso do abdomen prêso aos processos costiformes das vértebras lombares e oblíquo interno do abdomen, sendo o primeiro facilmente reconhecido pela orientação transversal de suas fibras musculares. Dois músculos pelvitrocantéricos, aparecem bem distintos sob o corpo e processo costiforme das vértebras lombares: os $\mathrm{mm}$. pequeno e grande psoas. Estes dois músculos constituem o filet mignon, peça que não consideramos como segmento à parte, pois, não é retirado da carcassa pela quasi totalidade dos retalhistas, fazendo parte, portanto, do filet de lombo com o qual é vendido.

$\mathrm{Na}$ face externa do filet de lombo assinalamos, nos espaços intercostais, os mm. intercostais externos e sôbre estes o pequeno m. 
denteado dorsal caudal. Recobrindo grande parte da face externa do segmento que descrevemos, o $\mathrm{m}$. oblíquo externo do abdomen em forma de uma longa lâmina muscular. Ao nivel da goteira vértebro-costal o grupo dos mm. espinodorsais distintos em: mm. interespinhosos, intertransversários lombares e transversoespinhoso. Vêm-se em córte, formando uma massa comum que ocupa quasi tôda a goteira vertebral os $\mathrm{mm}$. longo espinhoso, longo costal e longo dorsal. Esste último acolhe em um sulco ao nivel da sua origem o caput piramidal do $\mathrm{m}$. glúteo médio que nos bovinos apenas ultrapassa cranialmente o nivel da tuberosidade ilíaca externa.

Observado o filet de lombo em córte transversal distinguimos dois agrupamentos musculares situados dorsal e ventralmente aos processos costiformes e corpo das vértebras lombares. O ventral constitue como vimos o filet mignon, enquanto que o alojado na goteira vertebral é denominado contra-filet. Designa-se com o nome de rabo do filet o segmento que pende dos processos costiformes das vértebras lombares, constituido pelos músculos largos do abdomen.

Alcatre: (Figs. I, 9 - III, 4)

Base óssea - Sacrum e íleo sem o ângulo cotilóide.

Base muscular - Observam-se na face interna os seguintes músculos: pequeno psoas, grande psoas e ilíaco, intimamente unidos, oblíquo interno do abdomen e um pequeno segmento do $\mathrm{m}$. sartório ao nivel de sua inserção.

Os músculos glúteos constituem a base muscular principal da face externa, representados pelas porções ilíaca e vertebral do $\mathrm{m}$. glúteo superficial confundidas a primeira com o tensor da fascia lata e a segunda com o $\mathrm{m}$. paramenral e pela quasi totalidade dos $\mathrm{mm}$. glúteo médio, glúteo profundo e escansório.

Nota-se ainda o m. oblíquo externo do abdomen e a inserção do $\mathrm{m}$. reto anterior da coxa. Ao nivel da goteira vertebral, a massa comum que o $\mathrm{m}$. longo dorsal forma com os $\mathrm{mm}$. longo espinhoso e longo costal, acolhe em um sulco o volumoso $\mathrm{m}$. glúteo médio.

Patinho: (Fig. IV, 1).

Base óssea - Femur sem o grande trocanter e sem a epífise distal; rótula.

Base muscular - Podemos considerar a base muscular do patinho como que exclusivamente formada pelo m. quadríceps femural, com suas porções: mm. reto anterior da coxa, vasto lateral, vasto medial e vasto intermédio (Fig. IX, 1). Consegue-se reconhecer esta peça pela direção do $\mathrm{m}$. sartório e pelas inserções dos mm. grande 
psoas, ilíaco, glúteo superficial, tensor da fascia lata, glúteo médio, glúteo profundo e escansório; ainda, pelas inserções dos mm. obturador interno, obturador externo e gêmeos da bacia, na fossa subtrocantérica e pela origem dos $\mathrm{mm}$. gêmeos da perna. Sôbre o corpo do femur podem-se notar as superfícies onde tomam inserção os mm. adutor, quadrado femural e pectíneo.

Coxão mole: (Fig. IX, 2).

Base óssea - Pubis, ísquio e ângulo cotilóide do íleo; metade medial da epífise distal do femur compreendendo o lábio troclear e o côndilo. Tíbia sem o côndilo lateral e sem a epífise distal.

Base muscular - (Fig. VIII) Ao nivel do coxal encontra-se o m. obturador interno considerado como músculo interno da bacia e os mm. obturador externo, gêmeos da bacia e quadrado femural estudados como músculos profundos da bacia. Devemos assinalar tambem a presença de mínima porção, a mais caudal, de um dos músculos externos superficiais da bacia : o m. escansório. No coxão mole vêm-se ainda os seguintes músculos da coxa: 1) do grupo anterior: um segmento do $\mathrm{m}$. sartório (costureiro); 2) do grupo medial: os $\mathrm{mm}$. pectíneo, adutor e reto medial da coxa, êste formando o plano mais superficial, os outros dois o plano profundo; 3 ) do grupo posterior: parte das inserções isquiática do $\mathrm{m}$. longo vasto, $\mathrm{o} \mathrm{m}$. semimembranoso e reduzida porção do $\mathrm{m}$. semitendinoso (Fig. X). Do segmento que estudamos fazem parte os seguintes músculos da perna: 1) grupo anterior ou dos extensores, compreendendo os mm. tibial anterior, femurometatársico, extensor anterior das falanges, dividido em extensor próprio do dedo medial e extensor comum dos dedos; todos estes músculos são seccionados longitudinalmente, de modo que na realidade são representados no coxão mole, pelas respectivas metades mediais; 2) grupo posterior ou dos flexores; inclue somente os $\mathrm{mm}$. poplitêo, flexor profundo das falanges, flexor oblíquo do metatarso e pequena porção dos gêmeos da perna. Êste agrupamento muscular é seccionado de modo idêntico ao que descrevemos para o grupo anterior, figurando portanto, no coxão mole unicamente as partes mediais.

Devemos contudo frizar que os $\mathrm{mm}$. da perna, acima enumerados, embora vendidos com o coxão mole e portanto alcançando valor de carne de primeira categoria, na realidade são enquadrados com a designação genérica de músculo, isto é, pertencem à terceira categoria. 
Coxão duro: (Figs. IV, 2 - IX, 3).

Base óssea - Metade lateral da epífise distal do femur compreendendo o côndilo e lábio troclear; côndilo lateral e epífise distal da tíbia; tarso.

Base muscular - E' quasi inteiramente constituida pelo $\mathrm{m}$. longo vasto (glúteo bíceps), do grupo posterior da coxa (Fig. IX, L. V.). Faz parte ainda do segmento em estudo a metade lateral resultante da secção longitudinal dos mm. flexores e extensores do metatarso e falanges, exceção feita dos mm. gastrocnêmio e flexor superficial das falanges. Os mm. poplitêo, flexor oblíquo do metatarso, flexor superficial e gastrocnêmio concorrem unicamente com os segmentos de origem para a formação da base muscular do coxão duro. Aos flexores e extensores do metatarso e falanges, já enumerados quando tratámos do coxão mole, acrescentaremos ao grupo anterior o m. extensor lateral das falanges que, nos ruminantes, tem o valor de extensor próprio do dedo lateral; no grupo posterior os $\mathrm{mm}$. flexor superficial das falanges e solear não seccionado.

À exceção do $\mathrm{m}$. longo vasto que constitue o coxão duro propriamente dito, os demais músculos citados têm valor comercial de carne de $3 .^{\text {a }}$ categoria, sendo vendidos com o nome de músculo.

Lagarto: (Fig. IX, 4).

$\mathrm{O} \mathrm{m}$. semitendinoso forma a base muscular dêste segmento trazendo junto pequena porção da tuberosidade isquiática (Fig. X, r). Acompanham o m. semitendinoso a parte mais caudal do $\mathrm{m}$. longo vasto e os $\mathrm{mm}$. gastrocnêmio e flexor superficial das falanges, estes dois últimos vendidos como músculo.

Com referência à técnica de operações, nomenclatura e categorias em uso no mercado da Capital Federal, relataremos de modo sucinto as principais diferenças apresentadas comparativamente ao que acabamos de descrever.

Dianteiro: - A principal diferença notada é a referente ao córte que separa o peito do assem, praticado paralelamente ao esterno, ao nivel da articulação costo-esternal, cabendo assim ao peito mínima porção do gradil torácico. A altura em que é praticado êste córte tem por consequência o aumento de pêso do assem em detrimento do peito e por outro lado evidencía o interesse do retalhista em obter maior quantidade de carne de $2 .^{a}$ categoria. 
O membro torácico é denominado pá, sendo êste o único segmento do dianteiro cuja nomenclatura não corresponde à de São Paulo. Classificado como de 2.a categoria êste segmento, depois de sofrer a retirada do húmero, rádio e cúbito, passa a ser vendido como de $1 .{ }^{a}$ categoria pá desossada.

Traseiro: - Retirado o coxão inicia-se a divisão da barca ou alcatre inteiro, como é melhor conhecido, por uma operação em tudo semelhante à técnica usada em São Paulo; as variantes a assinalar dizem respeito apenas à nomenclatura. Assim a ponta de agulha, é denominada costela e o alcatre, filet de lombo e filet de costela são chamados, respectivamente, ponta de alcatre, filet de alcatre, e filet de lombo ou charneira.

A técnica de retalho, as bases óssea e muscular dos segmentos do coxão correspondem às descritas para São Paulo; todavia a nomenclatura apresenta as diferenças seguintes: o patinho é conhecido como pato, o coxão mole e o coxão duro são designados respectivamente chã de dentro e chã de fora ou perna.

O lagarto tendo como base muscular principal o m. semitendinoso é vendido com o nome de lagarto do fim ou então, acompanha o segmento com o qual está em conexão, isto é, o chã de fora ou perna.

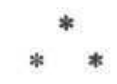

Os diversos segmentos, cuja técnica de córte e bases anatômicas acabámos de estudar, se agrupam em quatro categorias de acôrdo com seu valor venal, satisfazendo assim às exigências do mercado retalhista da cidade de São Paulo.

Da primeira categoria fazem parte: filet de lombo, filet de costela, alcatre, coxão duro, coxão mole, patinho, lagarto e fraldinha. A segunda é representada pelo braço. A terceira compreende: assem, pescoço, músculos e capa do filet e na quarta categoria se enquadram ponta de agulha e peito.

A classificação oficial, cumpre assinalar, não é extritamente seguida por todos os retalhistas que introduzem algumas modificações quanto às categorias quasi sempre com tendência especulativa.

De preço muito elevado, ultrapassando em muito o valor dos segmentos de primeira categoria, o filet mignon vem em peças separadas diretamente dos Matadouros, para alguns açougues de consumidores mais exigentes. De tudo o que ficou exposto, depreende-se que os melhores segmentos sob o ponto de vista culinário, alcançando 
preços mais elevados são aqueles retirados do quarto traseiro. De fato, esta porção da carcassa fornece todos os segmentos de primeira categoria.

A cauda e vísceras, enfeixadas sob o nome genérico de miúdos, são vendidas em separado, e não acompanham as carcassas.

Aos Srs. J. Walsh e J. de Almeida, superintendente geral e superintendente divisional do Frigorífico Armour de São Paulo agradecemos a oferta do material para estudo. Às firmas Oliveira \& Irmãos, da Capital Federal e Cafalli \& Cia., desta Capital, gratos por nos franquearem seus estabelecimentos nas visitas repetidas que aí realizámos.

\section{BIBLIOGRAFIA}

1939 - A proposito di classifica degli animali da macello - Azione Veterinaria - 8, 227.

Bertolini, G. \& Cazzella, A. - 1928 - Ispezione delle carni. Igiene generale. Torino, Unione tipografico editrice.

Cristol, P. - 1935 - Précis de Chimie Biologique médicale. Paris, Masson et Cie. éditeurs.

Ellengerger, W. \& Baum, H. - 1932 - Handbuch der Vergleischenden Anatomie der Haustiere. Siebzehnte Aufl. Berlim, Julius Springer.

Ellenberger, W. Baum, H. \& Dittrich, H. - 1925 - Handbuch der Anatomie der Tiere für Künstler Bd, 2: Anatomie des Rindes 3 Auf. Leipzig, Dieterich'sche Verlagsbuchhandlung.

Ewing, W. \& Flora Carl - 1935 - Cutting, Curing and Canning. Pork and Beef Missouri, Boll. Agric, circ. 318.

Llosa, J. P. TORRes de la -1937 - Condiciones que debe tener un reproductor vacuno para carniceria. An. Fac. Vet. Montevideo, 2/3, 277/88.

Martin, P. \& Schauder, W. - 1934 - Lehrbuch der Anatomie der Haustiere III Band, I Teil Stuttgart, Schickhardt \& Ebner.

Montané, L. \& Bourdelle, E. - 1917 - Anatomie Régionale des Animaux Domestiques, II vol. Paris, J. B. Baillière et Fils.

Piettre, M. - 1921 - Inspection des viandes et des aliments d'origine carnée. Industrie et législation, lére p: - Viande saine. Paris, J. B. Baillière et Fils.

Porsson, J. - 1938 - La coupe dite «de Paris» des animaux de boucherie. Ses bases anatomiques. Paris, Vigot Frères.

Roux, P. - 1938 - Le Marché de la Viande au détail. Le problème de la réglementation. Rev. Zootechnie, 17, (8), 103/45.

SABA, M. - 1936 - Inspection des viandes et abattoirs en Syrie. Rec. Méd. Vét. Exotique École Alfort, 9, 70/83, 102/17.

VAle, J. Miranda Do - 1935 - Inquérito ao abastecimento de carne bovina no Continente e Ilhas adjacentes, Lisbôa, Instituto Superior de Ciências Econômicas e Financeiras.

Zieoler, P. T. - 1928 - Market meats. Pennsylvania Sta. Coll. Circ. 118.

Zimmerl, U. - 1929 - Trattato di Anatomia Veterinaria, I vol. Milano, Francesco Vallardi. 


\section{EXPLICAÇOES DAS FIGURAS}

Fig. I - Face interna da meia carcassa. Incisões e segmentos.

$$
\begin{aligned}
& \text { A - quarto dianteiro; } \\
& \text { B - quarto traseiro; }
\end{aligned}
$$

a a' - traço da incisão ao nivel do $5 .^{\circ}$ espaço intercostal;

b b' - " " da face interna do torax da $5 a^{a}$ à $1 a^{\text {a }}$ costela;

c c'- " " vertical que interessa a $7 . a$ vértebra cervical, tangenciando a $1 . \mathrm{a}$ costela;

d d' - traço da incisão para retirada do $m$. reto do abdomen e da gordura da prega do gordinho;

e e' - traço da incisão para separar a «barca» do «coxão»;

f f' - " " " " a ponta de agulha da «barca»;

$\mathrm{g} \mathrm{g}^{\prime}-» "$ "

h h'

x - «barca»; $y$ - «coxão»; 1 - pescoço; 2 - assem; 3 - peito;

4 - braço; 5 - fraldinha; 6 - ponta de agulha; 7 - filet de costela; 8 filet de lombo; 9 - alcatre.

Fig. II - Brą̧o:

1 - músculo; 2 - contrapêso; 3 - braço.

Fig. III - Quarto traseiro:

1 - ponta de agulha; 2 - filet de costela; 3 - filet de lombo; 4 - alcatre; 5 - coxão.

Fig. IV - Coxão:

a-b - incisões ao nivel da diáfise e epífise distal da tíbia; c - incisão dos mm. extensores do metatarso e falanges; d - ligamentos tíbio-rotulianos seccionados; e - incisão da tróclea femural; 1 - patinho; 2 - coxão duro; 3 - contrapêso.

Fig. V - Insisões e músculos superficiais do quarto dianteiro e do coxão:

a a' - traço da incisão ao nivel do $5 .^{\circ}$ espaço intercostal;

b b'- " " da $5 .^{\mathrm{a}}$ à $1 . \mathrm{a}$ costela, seu prolongamento sôbre o m. esternocefálico;

c c’ - traço da incisão dos mm. braquiocefálico, omotraqueliano e trapézio;

d f - traço da incisão do $\mathrm{m}$. tensor da fascia lata;

f d' - 》 》 que atingindo a articulação coxo-femural se prolonga até à tuberosidade isquiática;

e e' - linha da incisão do $m$. longo vasto.

a $-\mathrm{m}$. trapézio; b - m. omotraqueliano; $\mathrm{c}-\mathrm{m}$. cleidooccipital; c' $-\mathrm{m}$. cleidomastoideo; $\mathrm{d}-\mathrm{m}$, esternocefálico; e-e' $-\mathrm{m}$. deltoide; $\mathrm{f}-\mathrm{m}$. grande extensor do antebraço; f' $-\mathrm{m}$. curto extensor do antebraço; $\mathrm{g}-\mathrm{m}$. esternohumeral; $\mathrm{h}-\mathrm{m}$. esternotroquiniano; $\mathrm{i}-\mathrm{m}$. denteado ventral do torax; $\mathrm{k}-\mathrm{m}$. grande dorsal; 1-1' - m. oblíquo esterno do abdomen e sua aponevrose; 
m-m' - m. denteado dorsal caudal e sua aponevrose de origem; n $-m$. oblíquo interno do abdomen; o-o' $-\mathrm{m}$. tensor da fascia lata; $\mathrm{p}-\mathrm{m}$. glúteo médio; $\mathrm{q}-\mathrm{m}$. longo vasto (glúteo bíceps); $\mathrm{r}-\mathrm{m}$. semitendinoso.

Fig. VI - Incisões e músculos profundos do quarto dianteiro:

a a' - traço da incisão ao nivel do 5.0 espaço intercostal;

b b'- 》 " da 5. a à $^{1 . a}$ costela;

c c'- " " da cartilagem do omoplata.

c' - m. braquiocefálico; d - m. esternocefálico; f $-\mathrm{m}$. grande extensor do antebraço; f' $-\mathrm{m}$. curto extensor do antebraço; $\mathrm{g}-\mathrm{m}$. esternohumeral; $\mathrm{h}-\mathrm{m}$. esternotroquiniano; $\mathrm{i}-\mathrm{m}$. denteado ventral do torax; $\mathrm{i}-\mathrm{m}$. angular da ,espadua; $k-m$. grande dorsal; $1-m$. oblíquo externo do abdomen; v' $-\mathrm{m}$. bíceps braquial; $\mathrm{x}-\mathrm{m}$. rombóide; $\mathrm{z}-\mathrm{m}$. supraespinhoso; $\mathrm{z}$ '-z" $-\mathrm{m}$. infraespinhoso; w - m. esplênio.

Fig. VII - Quarto dianteiro:

Membro torácico e metade ventral do gradil torácico reunidos pelos mm. denteado ventral, angular da espádua e rombóide à metade dorsal do gradil e pescoço.

Fig. VIII - Face medial da coxa:

a a' - traço da incisão entre os mm. sartório e quadríceps femural.

I. P. - m. ileopsoas; O. I. - m. obturador interno; P. - m. pectíneo; P. P. - m. pequeno psoas; R. A. - m. reto anterior da coxa; R. M. $-\mathrm{m}$. reto medial da coxa; S. - m. sartório; S. M. - m. semimembranoso; S. T. semitendinoso; T. F. - m. tensor da fascia lata; V. M. - m. vasto medial.

Fig. IX - Córte transversal da coxa praticado pouco abaixo do meio do femur:

a f - incisão entre os mm. quadríceps e longo vasto;

c f $-\# 》 \#$ e sartório;

d f - 》 " " semimembranoso e semitendinoso;

$\mathrm{e} \mathrm{b}$ - 》 do $\mathrm{m}$. longo vasto próximo à sua margem caudal.

A. - m. adutor da coxa; L. V. - m. longo vasto; P. - m. pectíneo; R. A. - m. reto anterior da coxa; R. M. - m. reto medial da coxa; S. - m. sartório; S. M. - m. semimembranoso; S. T. - m. semitendinoso; V. I. m. vasto intermédio; V. L. - m. vasto lateral; V. M. - m. vasto medial; 1 - patinho; 2 - coxão mole; 3 - coxão duro; 4 - lagarto.

Fig. $\mathrm{X}-$ Coxão visto aboralmente:

f f' - incisão entre os mm. semitendinoso e semimembranoso, prolongando-se sôbre os mm. flexores do metatarso e falanges.

$\mathrm{P}-\mathrm{m}$. glúteo médio; q-q' $-\mathrm{m}$. longo vasto (glúteo bíceps); $\mathrm{r}-\mathrm{m}$. semitendinoso; $\mathrm{v}-\mathrm{m}$. semimembranoso; $\mathrm{w}-\mathrm{m}$. reto medial da coxa.

Fig. XI - Córte transversal do pescoço ao nivel da 4.a vértebra cervical:

A. E. - m. angular da espádua; B. $1-\mathrm{m}$. braquiocefálico (cleidooccipital); B. 2 - m. braquiocefálico (cleidomastoideo); E. C. - m. esternocefálico; E. I. - m. esternoioideo; E. T. - m. esternotireoideo; I. - m. inter- 
transversario; L. D. $1-$ m. longo dorsal (longuíssimo da cabeça); L. D. $2-$ $\mathrm{m}$. longo dorsal (longuíssimo do atlas); L. D. $3-\mathrm{m}$. longo dorsal (longuíssimo do pescoço ou transversário do pescoço); L. E. $1-\mathrm{m}$. longo espinhoso (porção da cabeça ou grande complexo); L. E. 2 - m. longo espinhoso (porção cervical); L. P. - m. longo do pescoço; M. - m. multífido (parte cervical); O. T. m. omotraqueliano; R. - m. rombóide; Sc. - m. escaleno; Sp. - m. esplênio; T. - m. trapézio; T. A. - m. traqueoatloideo.

Fig. XII - Córte transversal ao nivel da $4 \mathrm{a}^{\mathrm{a}}$ vértebra torácica, interessando o omoplata, a 4.a, 3. e 2.a costelas, esterno, húmero e rádio.

C. E. A. - m. curto extensor do antebraço; D. - m. deltóide; D. V. m. denteado ventral do torax; - E. A. - m. esternoaponevrótico; E. H. m. esternohumeral; E. T. - m. esternotroquiniano; G. E. A. - m. grande extensor do antebraço; G. R. - m. grande redondo; I. E. - m. infraespinhoso; L. C. - m. longo costal; L. D. - m. longo dorsal (longuíssimo do dorso); L. E. - m. longo espinhoso (porção dorsal); L. P. - m. longo do pescoẹo (parte torácica); M. - m. multífido (parte torácica); M. E. A. - m. mediano extensor do antebraço; R. - m. rombóide; S. E. $1-$ m. supraespinhoso; S. E. $2-\mathrm{m}$. subescapular; T. $-\mathrm{m}$. trapézio; T C. $-\mathrm{m}$. transverso das costelas.

Figs. V, VI e X - Adaptação das pranchas de Ellenberger, Baum \& Dittrich. Fig. VIII - Adaptação da prancha de MARTIN \& SCHAUder.

Figs. IX, XI e XII - Adaptação das figuras de Montané \& Bourdelle. 
$\begin{aligned} & \text { P. Mucciolo e O. M. de Paiva. } \\ & \text { Córtes de carne bovina em S. Paulo. }\end{aligned} \quad$ Rer. Fae. Med. Vet. S. Paulo, Vol. t, fasc. s-4
Fig. I

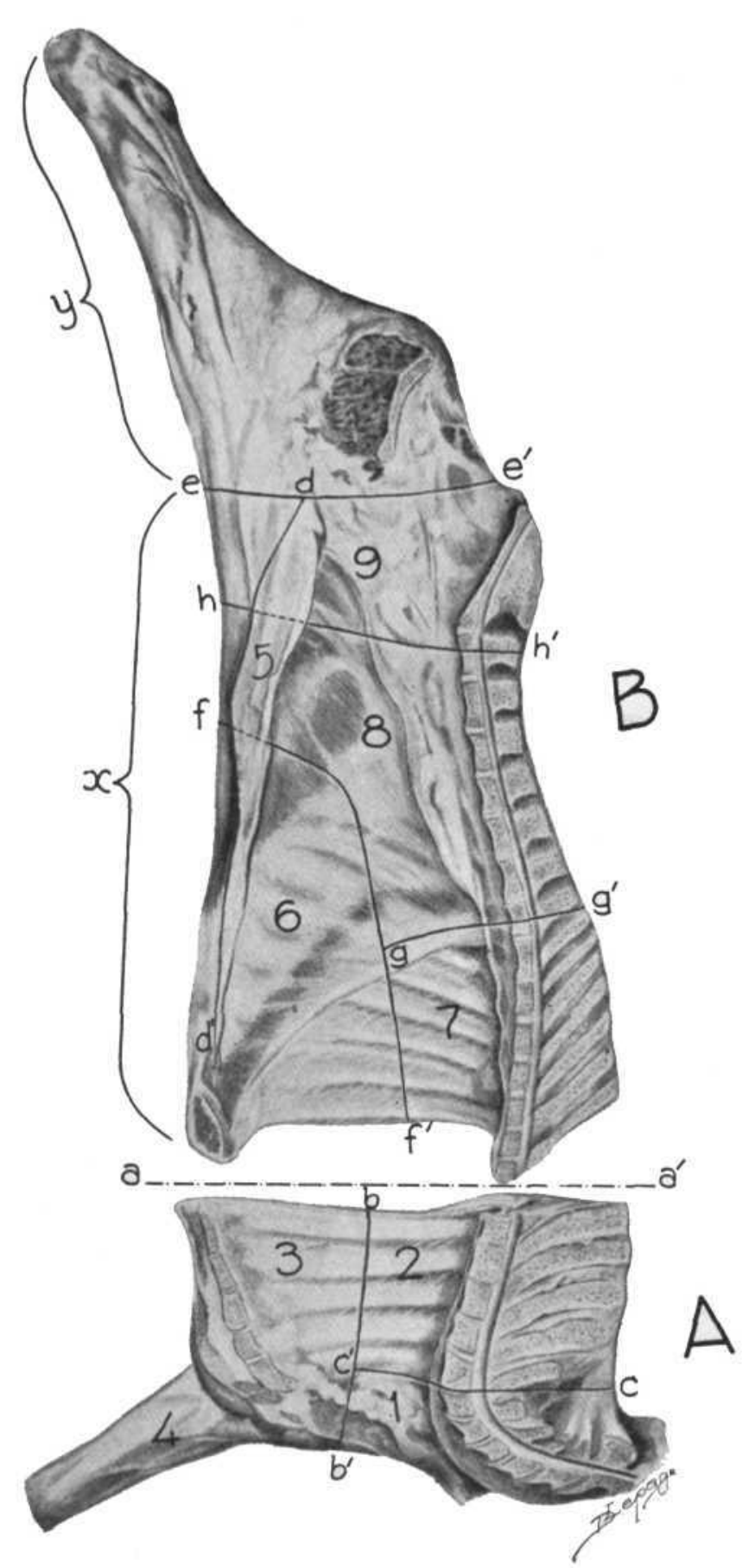


P. Mucciolo e O. M. de Paiva.

Córtes de carne bovina em S. Paulo.
Rev. Fac, Med. Vet, S, Paulo, Vol, 1, fase. s-s Fig. II

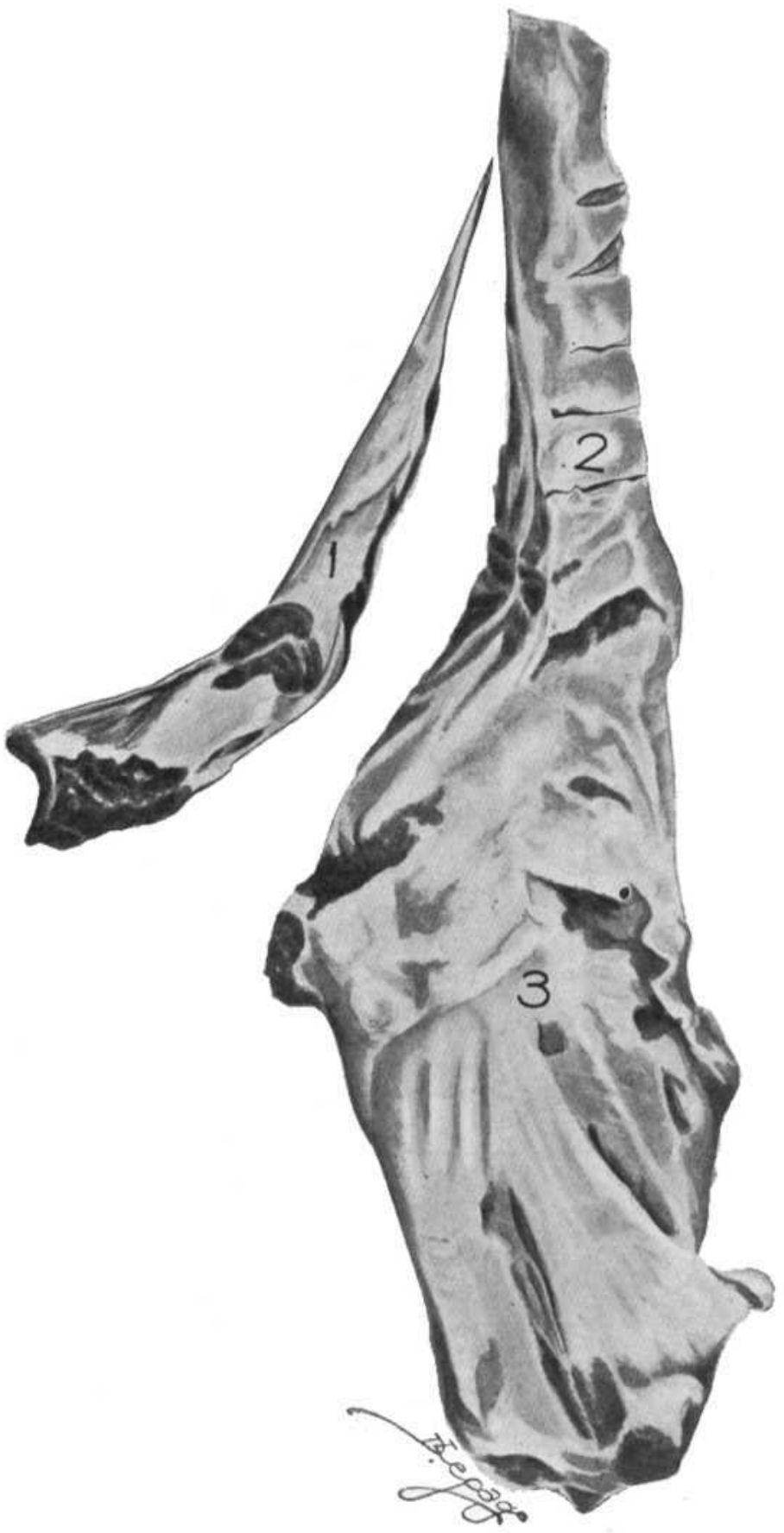


P. Mucciolo e O. M. de Paiva.

Córtes de carne bovina em S. Paulo.

Rev. Fac. Med. Vet. S. Paulo, Vol. 1, fasc, s-4 Fig. III

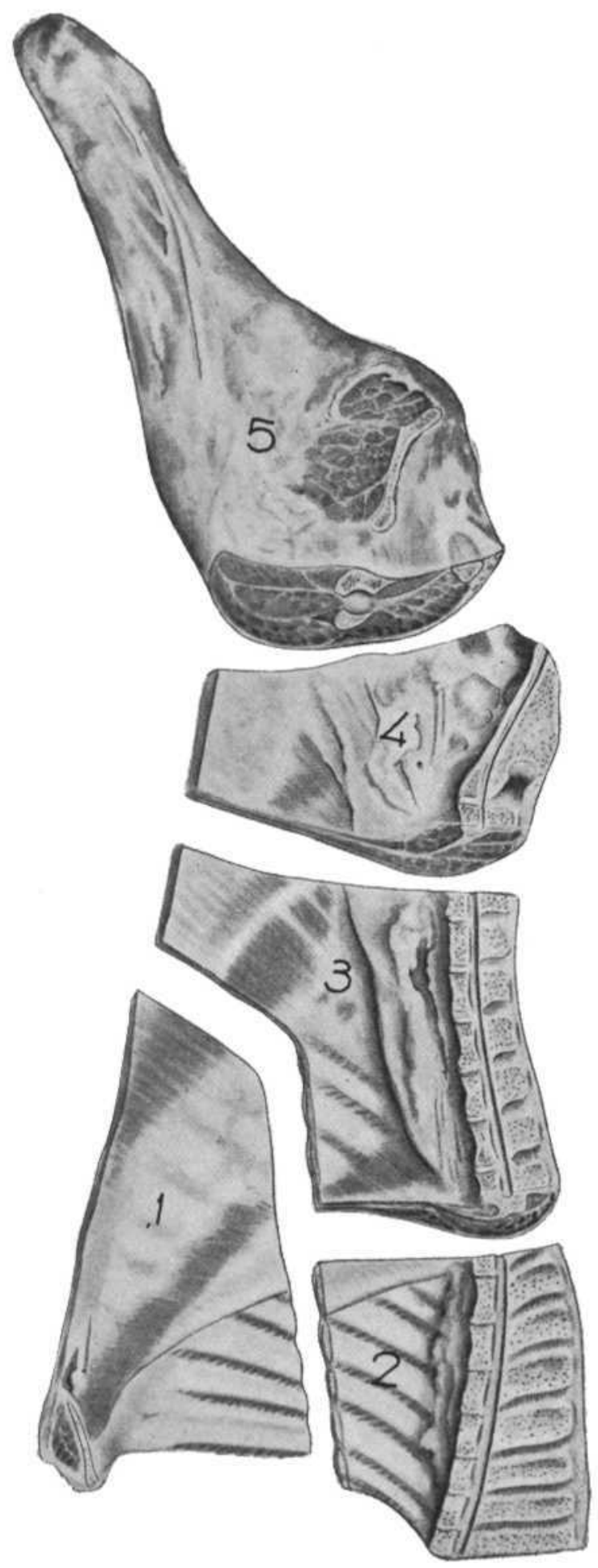




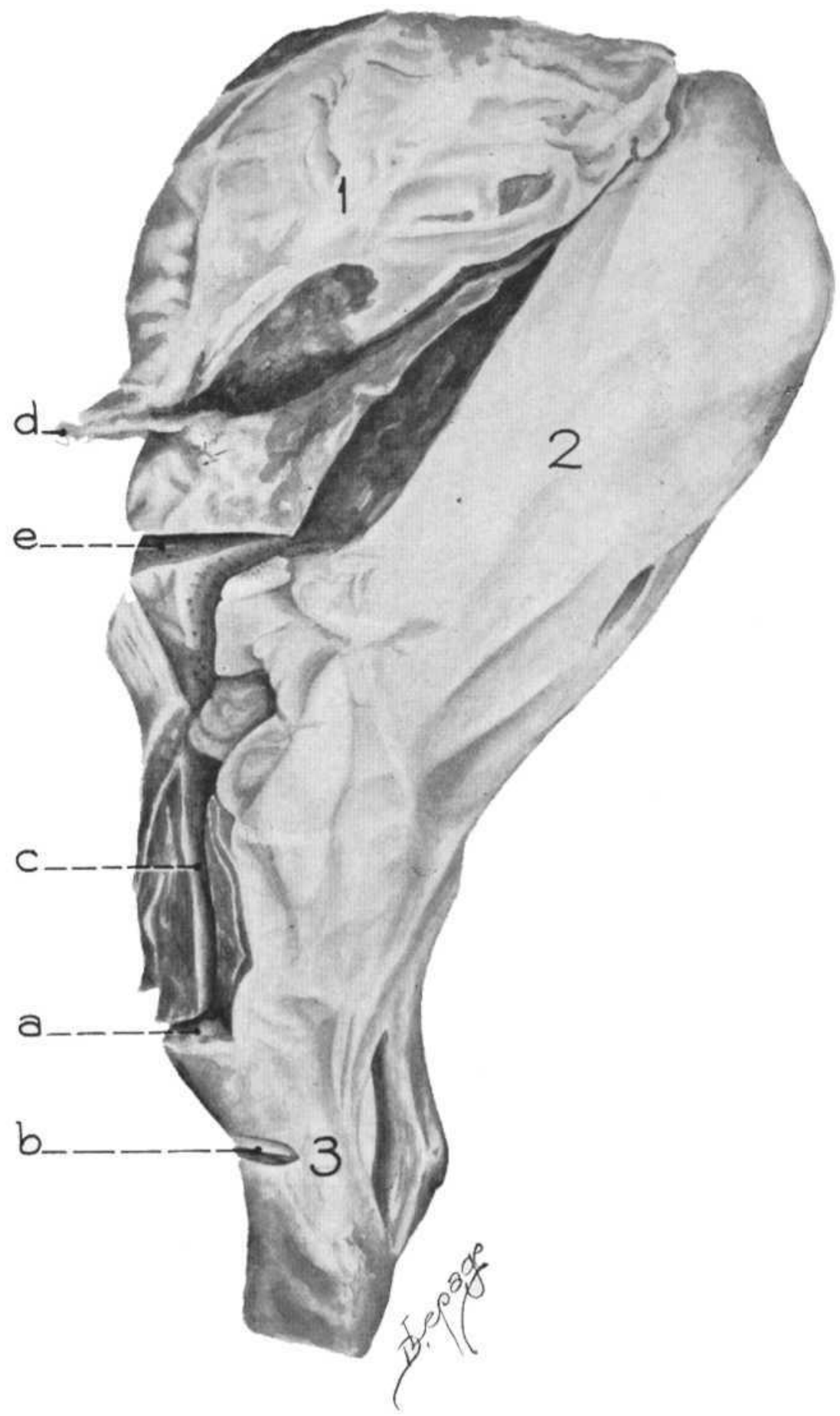




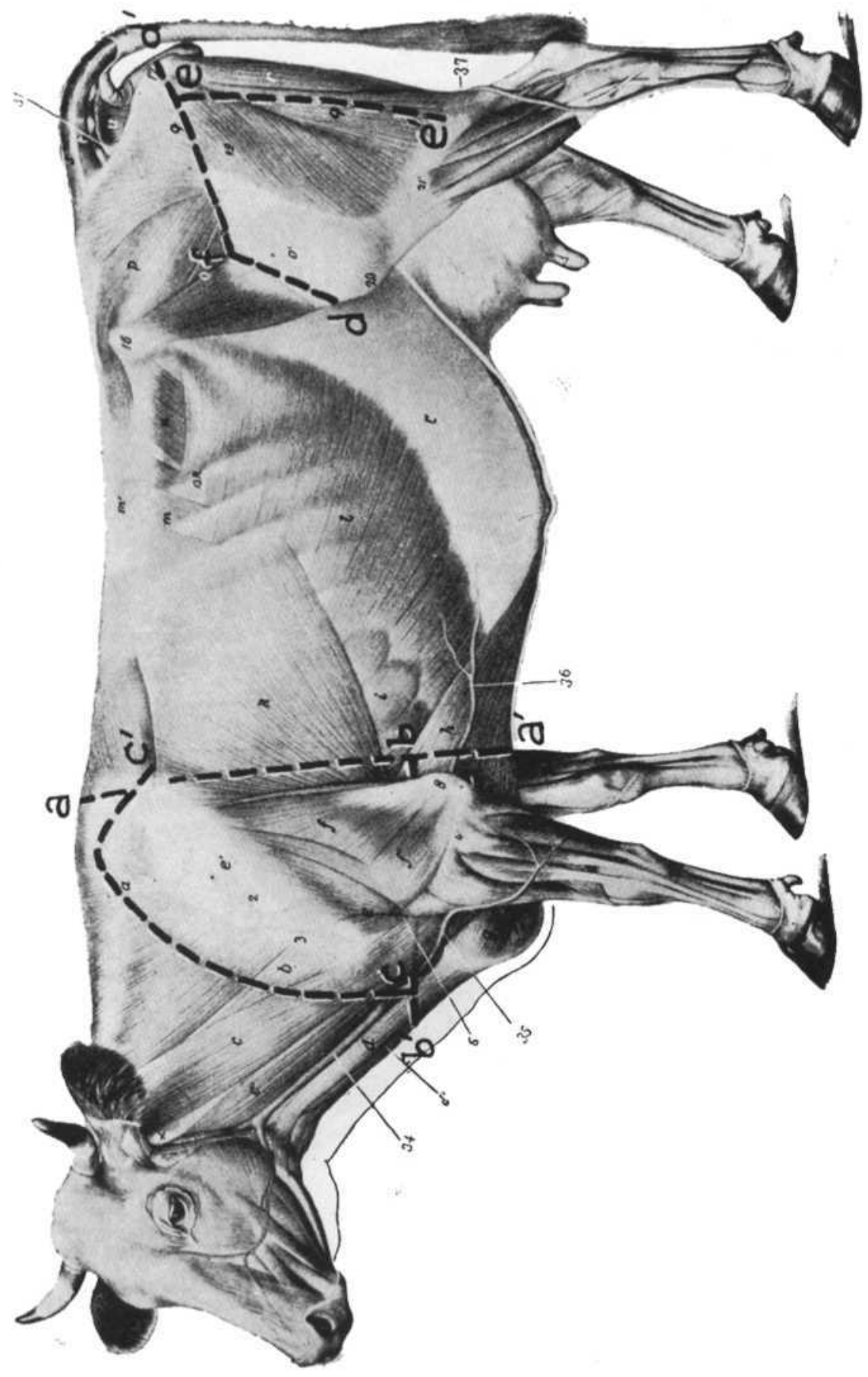


P. Mucciolo e O. M. de Paiva.

Córtes de carne bovina em S. Paulo.
Rev. Fac. Med. Vet. S. Paulo, Vol. 1, fasc. 3-4

Fig. VI

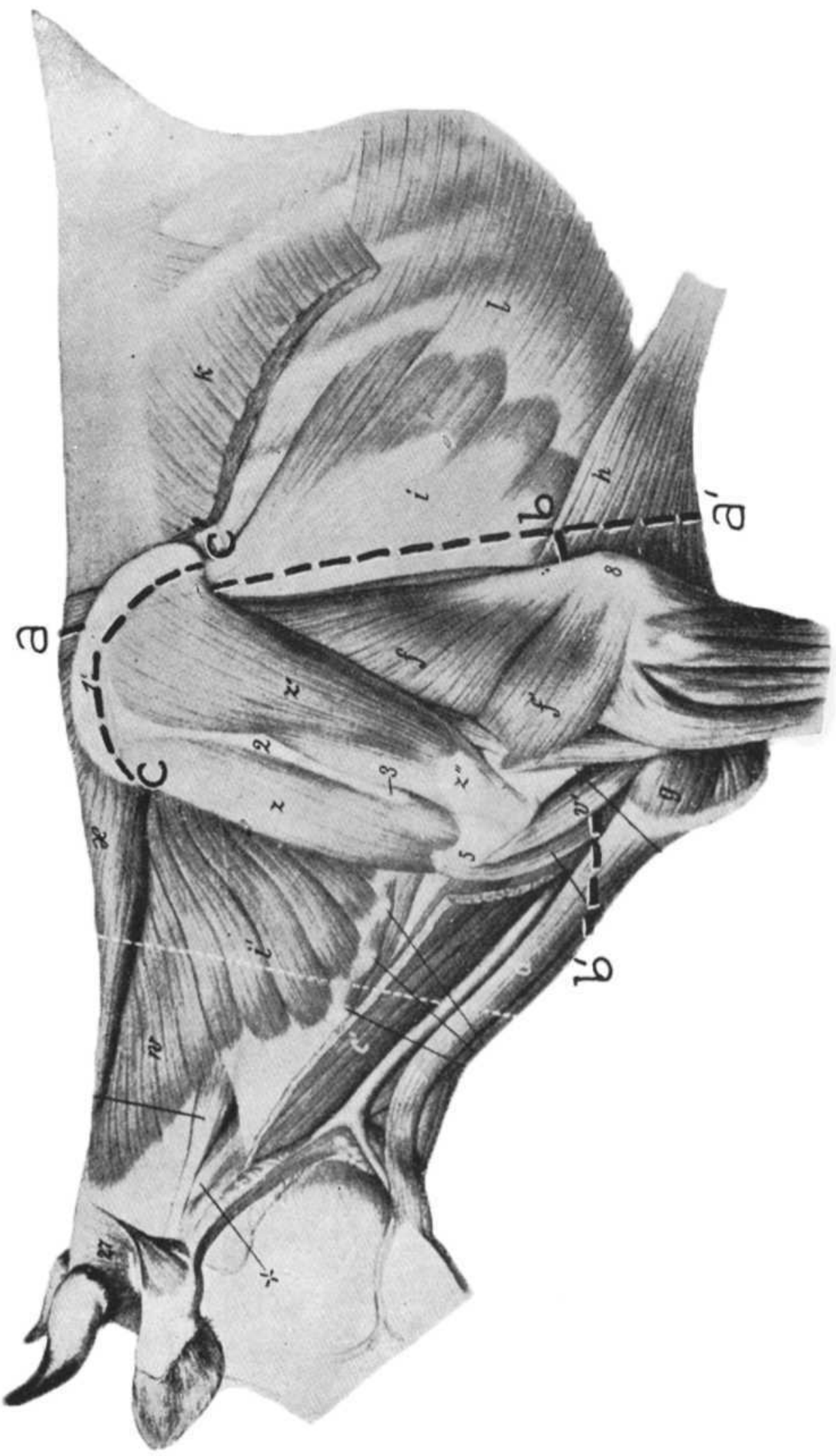


P. Mucciolo e O. M. de Paiva.

Córtes de carne bovina em S. Paulo.
Rev. Fac. Med. Vet, S, Paulo, Vol. 1, fase. 3-4

Fig. VII

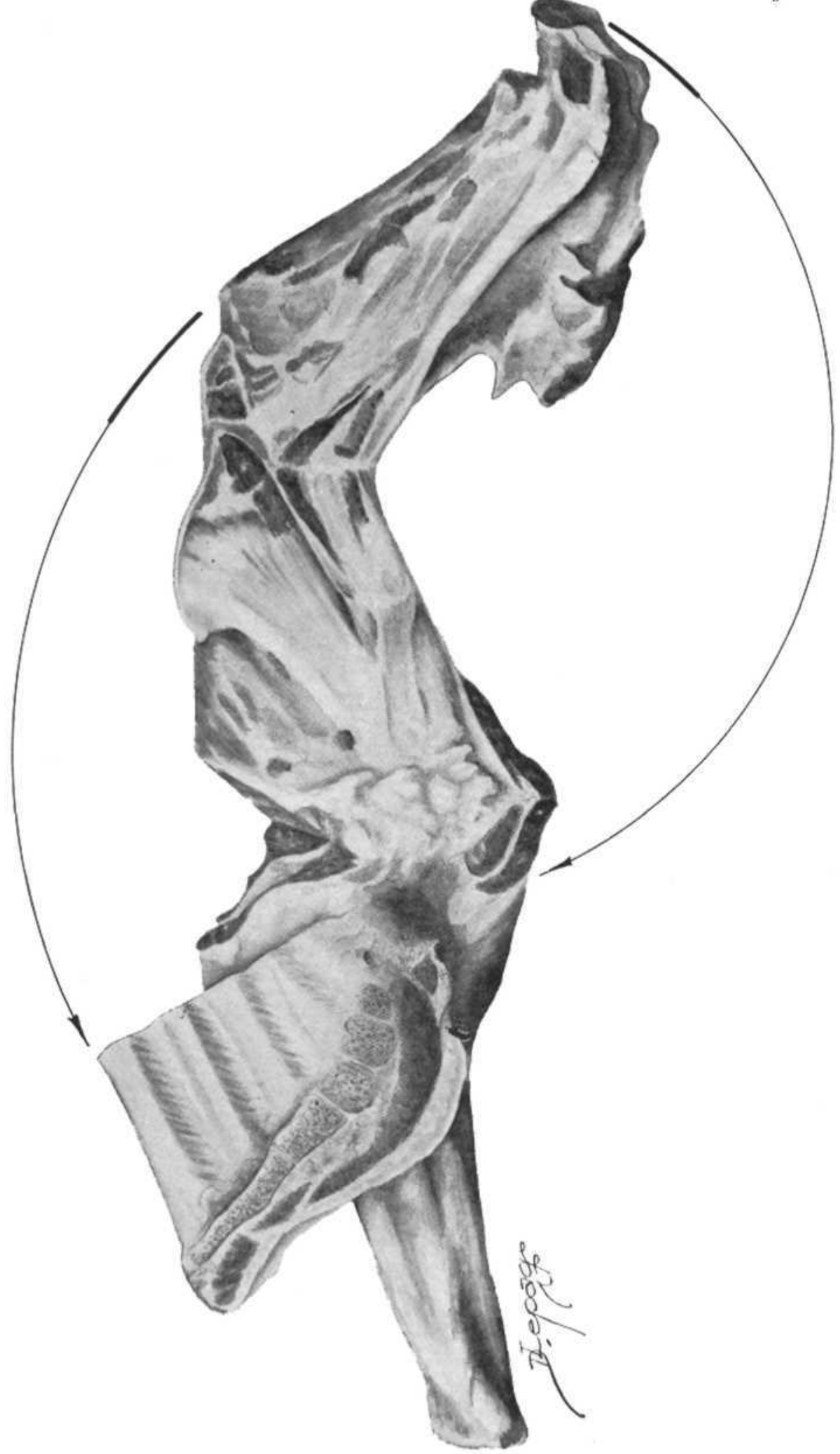


P. Mucciolo e O. M. de Paiva.

Córtes de carne bovina em S. Paulo.
Rev. Fac. Med. Vet. S. Paulo, Vol. 1, fase. 3-4

Fig, VIII

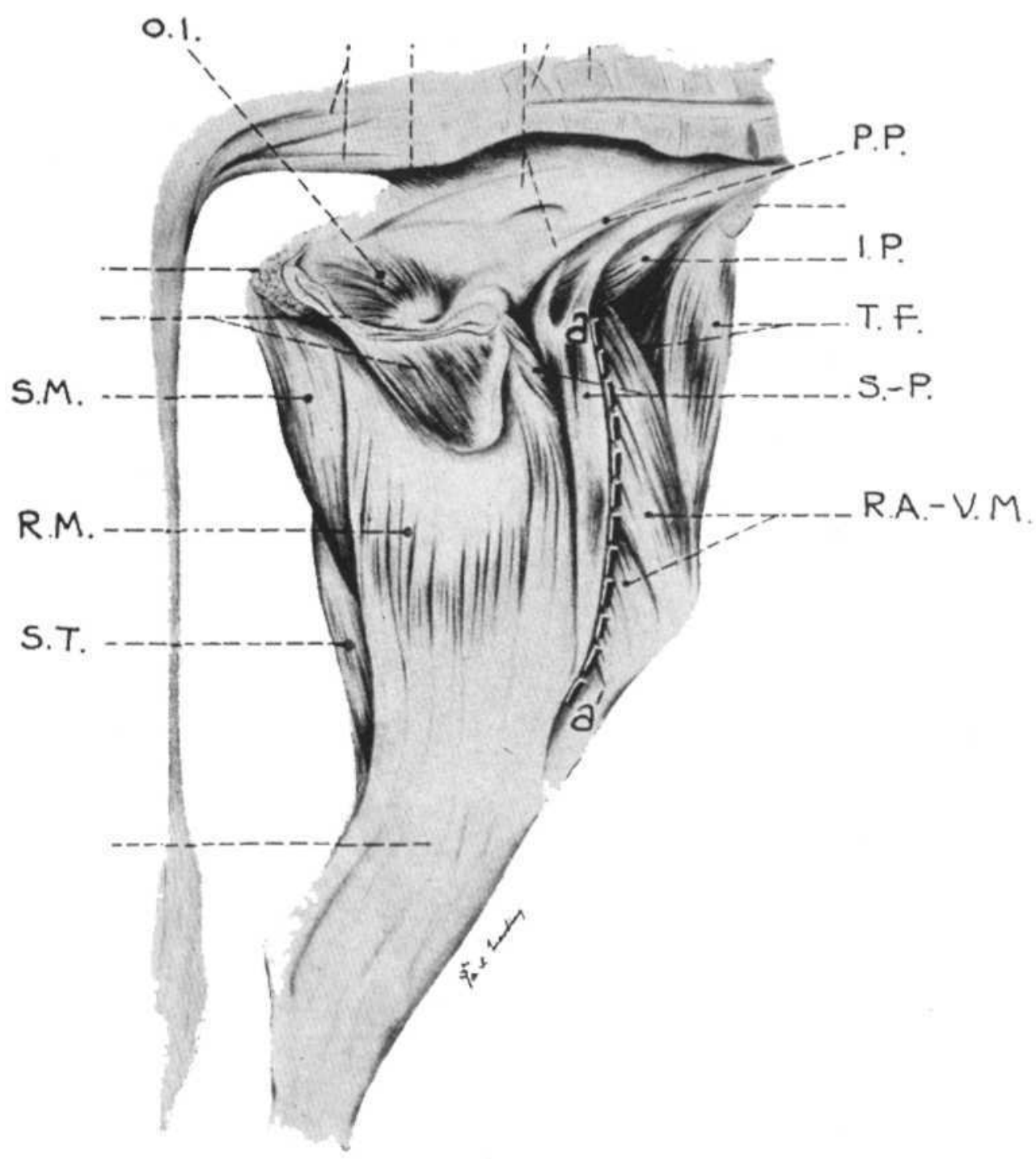


P. Mucciolo e O. M. de Paiva.

Córtes de carne bovina em S. Paulo.

Rev. Fac, Med. Vet. S. Paulo, Vol. 1, fase. s-s

Fig. IX

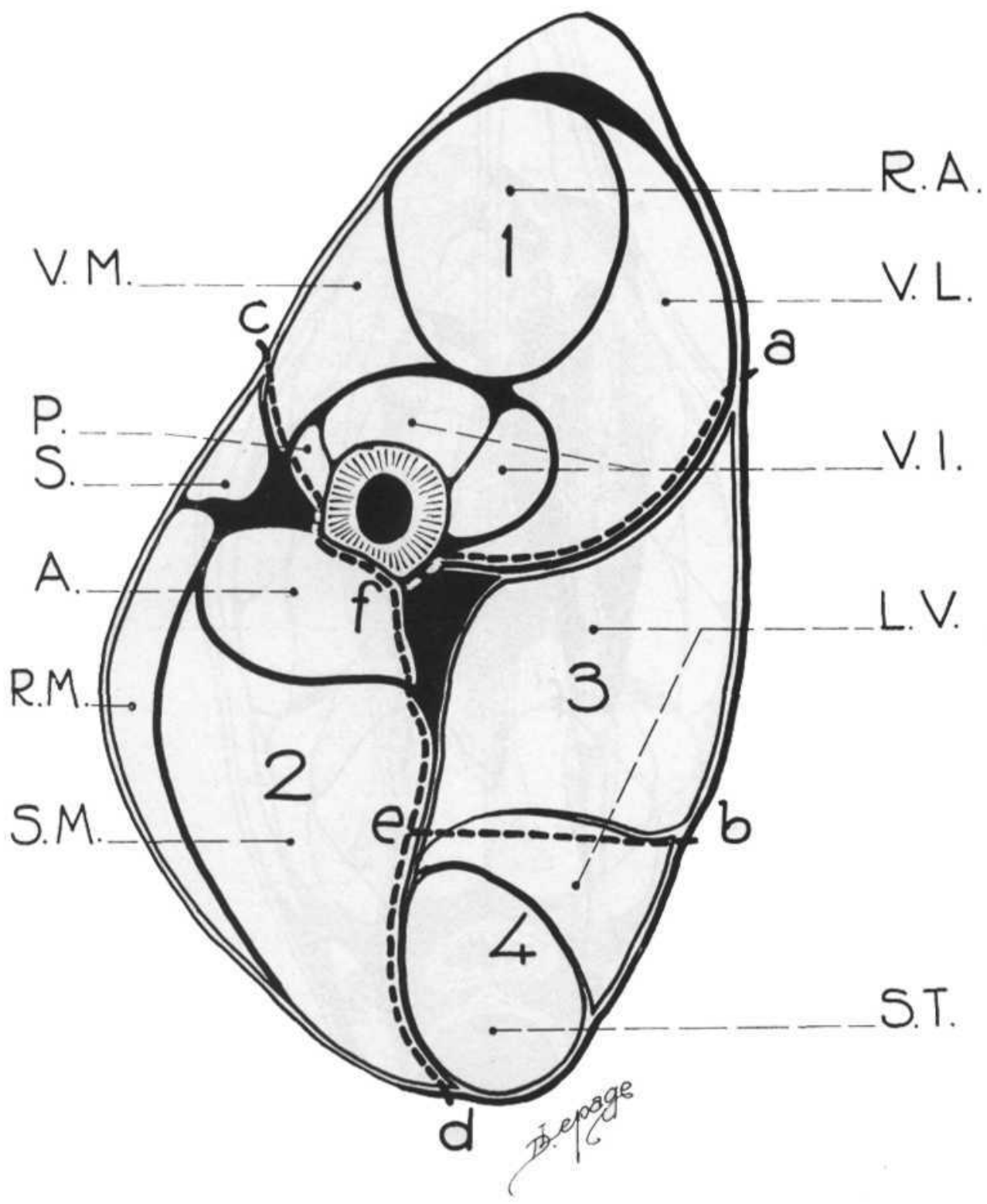


P. Mucciolo e O. M. de Paiva.

Córtes de carne bovina em S. Paulo.
Rev. Fac. Med. Vet. S. Paulo, Vol, 1, fase, s-4

Fig. $X$

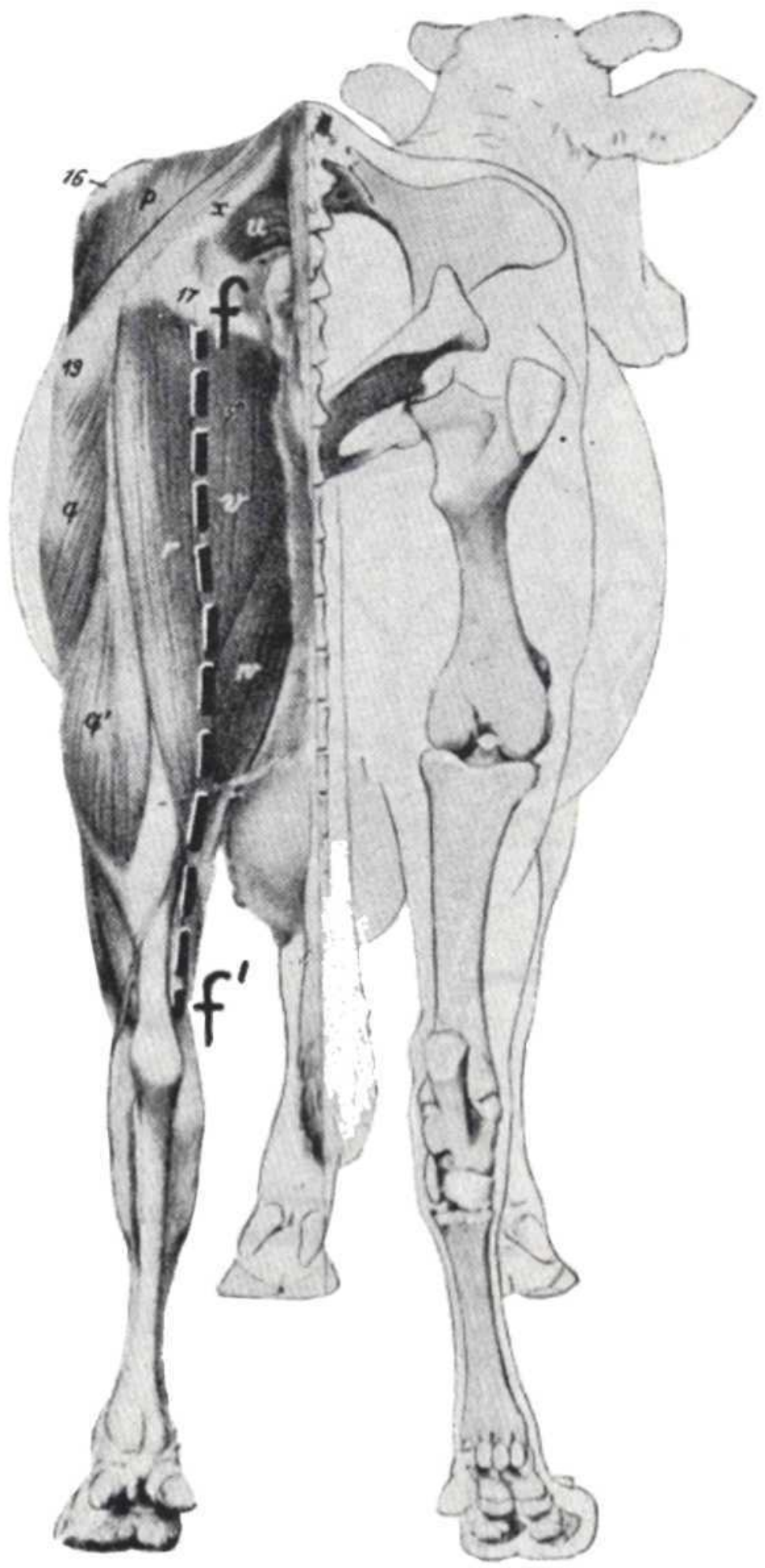




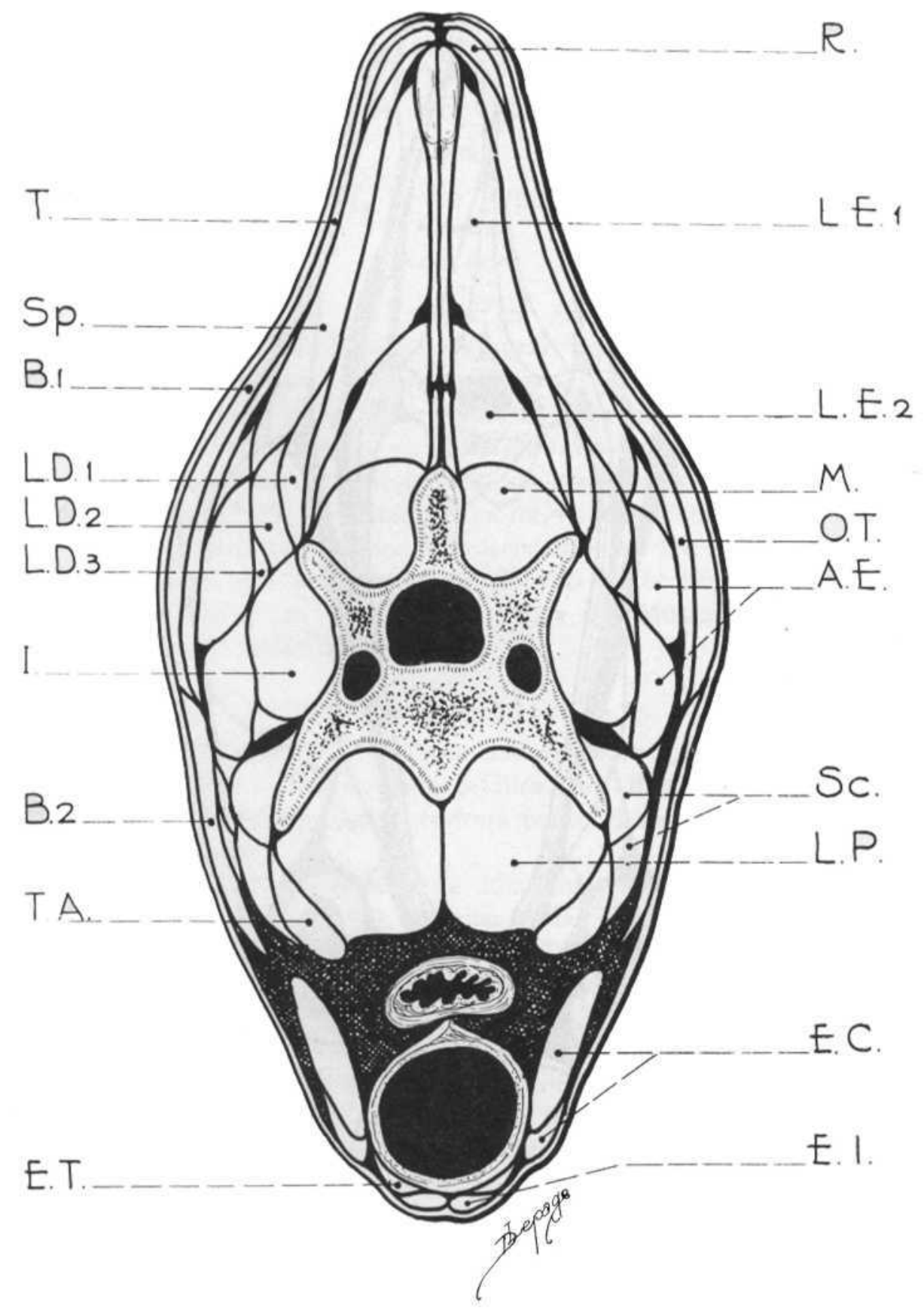


P. Mucciolo e O. M. de Priva.

Rev. Fac. Med. Vet. S. Paulo, Vol. 1, fase. s-4 Córtes de carne bovina em S. Paulo.

Fig. XII

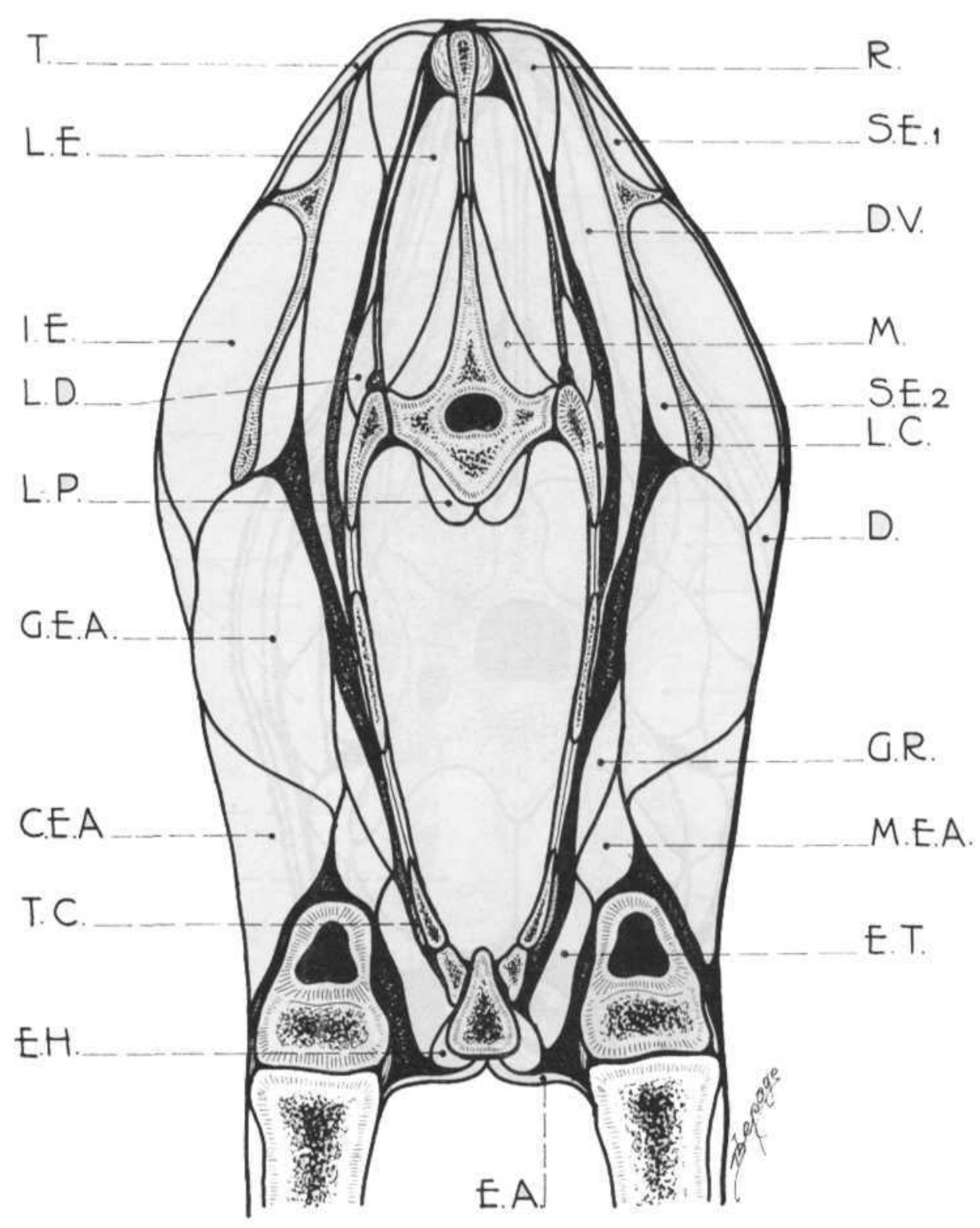

